\title{
Bryozoans (trepostomes and fenestellids) in the Zechstein Limestone (Wuchiapingian) of the North Sudetic Basin (SW Poland): palaeoecological implications
}

\author{
Urszula HARA $^{1, *}$, Mirosław SŁOWAKIEWICZ ${ }^{1,2}$ and Paweł RACZYŃSKI ${ }^{3}$ \\ 1 Polish Geological Institute - National Research Institute, Rakowiecka 4, 00-975 Warszawa, Poland \\ 2 Organic Geochemistry Unit, Bristol Biogeochemistry Research Centre and the Cabot Institute, School of Chemistry, \\ University of Bristol, Cantock's Close, BS8 1TS Bristol, United Kingdom \\ 3 Institute of Geological Sciences, Wrocław University, PI. Maksa Borna 9, 50-205 Wrocław, Poland
}

Hara U., Słowakiewicz M. and Raczyński P. (2013) Bryozoans (trepostomes and fenestellids) in the Zechstein Limestone (Wuchiapingian) of the North Sudetic Basin (SW Poland): palaeoecological implications. Geological Quarterly, 57 (3): 417-432, doi: 10.7306/gq.1103

A recently investigated Zechstein Limestone (Ca1, Wuchiapingian) bryozoan fauna from the Polish part of the Southern Permian Basin (SW Poland) is dominated volumetrically and taxonomically by fenestellids. In total six species from five genera are recognized, comprising two species of trepostomes belonging to Dyscritella Girty, 1911 and four fenestellids attributed to Kingopora Morozova, 1970, Kalvariella Morozova, 1970, Acanthocladia King, 1849 and Spinofenestella Termier and Termier, 1971. The greatest biodiversity of the bryozoans in the Ca1 profiles studied is within the slope facies where large, fan-shaped and funnel-shaped reticulate fenestellid colonies up to $10 \mathrm{~cm}$ high dominate. In contrast, bryozoans in the marginal (proximal) parts of the basin mostly comprise trepostomes, represented by encrusting plate-like or coil-shaped colonies of Dyscritella Girty, and commonly broken branched colonies of Acanthocladia King. The changes in the biotic composition of the bryozoans and the presence of a dominant colony growth form in the stratigraphical profile of the Ca1 reflect the depositional environment and water energy. These factors stimulate the successive stages of the development of the biota and their settlement, marked by the rich productid-fenestellid assemblages typical of the offshore setting, with the maximum depth in the middle part of the Ca1 in the Grodziec Syncline. The proximal tempestites and foreshore facies of the upper part of the Ca1 (Leszczyna Syncline) terminate the sedimentary cycle of the Ca1, with the remnant, broken bryozoans of Acanthocladia and fenestellids. The relationship between the taxonomic composition, colony growth-patterns, associated biota, and sedimentary structures points to slow sedimentation rate on slope and basin floor of the Ca1 carbonate platform. The fenestellids which are dominated in the studied biota by the reticulate and pinnate colonies of Spinofenestella, Kingopora, Kalvariella and Acanthocladia mark a close palaeogeographical link with the Zechstein (Ca1) bryozoans of Great Britain, Germany and the southern Baltic region.

Key words: bryozoans, Late Permian, Zechstein, taxonomy, ecology.

\section{INTRODUCTION}

Permian bryozoan faunas are, in terms of overall composition, rather similar to those of the Carboniferous, a time when bryozoan abundance and diversity were dominated by stenolaemates of the order Trepostomida Ulrich and Fenestellida Astrova and Morozova. Due to their abundance, taxonomical and morphological differentiation, bryozoans were important components of shallow-marine Zechstein carbonate environments before the end-Permian global mass extinction (Gilmour and Morozova, 1999).

\section{* Corresponding author, e-mail: urszula.hara@pgi.gov.pl}

Received: February 8, 2013; accepted: March 29, 2013; first published online: May 23, 2013
Zechstein bryozoans were first studied systematically in the 19th century in Germany and NE England by Schlotheim (1820) and King (1850), respectively. Later work was undertaken by Korn (1930), Dreyer (1961), Taylor (1980, 1985), Southwood (1985, 1990) and Ernst (2001a, b). The very first record of Zechstein faunas from Lower Silesia (Fig. 1) was reported by Geinitz (1861-1862) and Langenham (1899). In addition, the earliest references to the occurrence of bryozoans in the North Sudetic Basin are those of Riedel (1917), Gunia (1962), Morozova (1970) and Raczyński (1996). The most extensive systematic works on Polish Zechstein bryozoans were published by Kłapciński (1971) and Kłapciński and Karwowski (1981) from western Poland who described eight species dominated by fenestellids.

The great majority of the Zechstein species come from Germany where 17 species belonging to nine genera of trepostomes and fenestellids and one cyclostome were described by Ernst (2001a). Nevertheless, Late Permian (Zechstein) faunas appear to be not very rich compared to the Early Permian counterparts described from the Arctic (Morozova and Krutschinina, 
1986; Nakrem, 1994), and the United States (Zimmerman and Cuffey, 1987), where more than 160 taxa have been recorded (Gilmour and Morozova, 1999).

This paper gives the detailed description of the bryozoan fauna from the Zechstein Limestone (Ca1) of SW Poland (Fig. 1A) and discusses the palaeoecological importance and distribution of trepostomes such as cosmopolitan genera of Dyscritella Girty and fenestellids Spinofenestella Termier and Termier, endemic Kalvariella Morozova, as well as Kingopora Morozova restricted to the Northern Hemisphere and polyphyletic Acanthocladia King.

\section{GEOLOGICAL SETTING AND STRATIGRAPHY}

The study area is located in the North Sudetic Basin (SW Poland) where Zechstein Limestone (Ca1) deposits are exposed in several abandoned quarries at Leszczyna, Kondratów, Grodziec and Nowy Kościół (Fig. 1B, C). Some specimens were also collected in the southwestern part of the North Sudetic Basin in the Lwówek Śląski Syncline, from the lower part of the Ca1 (Gościszów, Nawojów Śląski and Żarska Wieś; Fig. 1B). Marine waters of the Zechstein Sea rapidly transgressed over the present day North Sea in Late Permian into the Northern Permian Basin and Southern Permian Basin through a strait located between Scandinavia and Greenland ca. 258,5 Ma ago (Gradstein et al., 2012; Kiersnowski 2013), resulting in the deposition of thick (<1800 m) evaporite-carbonate sequences. At present the Lower Zechstein outcrops in Poland are only located at the margins of the SPB, in its southwestern and southern parts. The Lower Zechstein rocks cropping out in SW Poland form a relatively narrow zone in the outer part of the North Sudetic Basin, a remnant of a Late Paleozoic intramontane trough formed as a result of the Variscan orogeny and subsequently tectonically reactivated in the Late Cretaceous when several local synclines were formed (e.g., Raczyński, 2010). Zechstein deposits within the Polish part of the SPB overlie Upper Rotliegend conglomerates and sandstones mostly consisting of fluvial, fan and minor aeolian deposits (Kiersnowski et al., 2010). The Zechstein section within the North Sudetic Basin is condensed and formed by deposits of the first ( $P Z 1=50$ to $120 \mathrm{~m}$ thick) and third (PZ3 <15 m thick) Zechstein cycles (Table 1; Peryt, 1978). The lowest part of the PZ1 cycle is represented by facies similar to those of the shallow-water copper-bearing claystones of the Kupferschiefer, which commonly contain continental plant remains in addition to marine bivalves and the inarticulate brachiopod Lingula. This facies represents the lower part of Ca1 deposits (Biernacka et al., 2005). All Ca1 deposits are usually 20 to $40 \mathrm{~m}$ thick and were deposited in a narrow $(20-30 \mathrm{~km})$ and long $(\sim 100 \mathrm{~km})$, WNW-ESE striking lagoon also associated with tidal flat and oolitic-oncolitic shoal environments (Raczyński, 1997). The PZ1 deposits are overlain by PZ3 Platy Dolomite (Ca3) carbonates (10-15 m thick) which consist of shallow-water facies containing Calcinema together with bivalves and gastropods. The carbonates are overlain by heterolithic deposits of the Permian to Triassic transitional series which form the youngest Zechstein deposits in the study area.

The Ca1 sections consist of ca. 10-40 m thick limestonemarl sequences (Fig. 2). The overall facies associations in the study area are given in Table 2 and these are: basal conglomerate, basal limestone, mottled marls, copper- and lead-bearing marls, massive limestones with claystones, and sandstones. Of note is a considerable part of the Ca1 succession formed of tempestite deposits (Figs. 2 and 3), which represent the nearshore part of the carbonate platform. The tempestites in the lower part of the Ca1 are distal, whereas those higher in the succession are proximal (Table 1). Most of the studied bryozoan fauna derives from mottled, lead-bearing and copperbearing marls of the Grodziec section (Fig. 2), and is dominated by the reticulate fenestellid bryozoans Kingopora baderi Ernst (Figs. 4J-M, 5A and 6) and Spinofenestella geinitzi (d'Orbigny) (Figs. $5 \mathrm{H}-\mathrm{L}$ and 7 ). The family Acanthocladiidae Zittel is also well-represented by Kalvariella typica Morozova (Fig. 5B, C) and Acanthocladia anceps (Schlotheim) (Figs. 5D-G, 8 and 9C). Trepostomes belonging to the family Dyscritellidae are represented by Dyscritella tubulosa Morozova (Figs. 4A-F and 9A) and D. microstoma Ernst (Figs. 3, 4G-I and 9B1, B2).

Although the distribution of the bryozoans in the marly calcareous series (mottled, copper- and lead- bearing marls) of the $\mathrm{Ca} 1$ is patchy this group is accompanied by a rich shallow-water biota represented by molluscs, gastropods, brachiopods, foraminifers and ostracods (Raczyński, 1996), which aid interpretation of the palaeoecology of the bryozoans (Mastalerz and Raczyński, 1993; Raczyński, 1996).

\section{MATERIAL AND METHODS}

The Zechstein bryozoan material was collected during 1990-1996 from seven localities spread over a distance of ca. $150 \mathrm{~km}$ within the North Sudetic Basin of SW Poland: Grodziec, Gościszów, Nawojów Ślaski, Żarska Wieś, Leszczyna, Nowy Kościół and Lwówek Śląski (Fig. 1B). The Grodziec locality yielded the richest bryozoan faunas. Of total 300 samples, forty-one were selected from three outcrops of the Zechstein Limestone (Ca1) for detailed taxonomical bryozoan studies. The twenty-four investigated samples were taken from the lower and upper part of the Ca1, of the Grodziec Syncline, which forms the most axial part of the North Sudetic Basin (Fig. $1 \mathrm{C})$, from mottled marls through copper-bearing marls to the lead-bearing beds (Table 1 and Fig. 2). Six investigated samples were collected in the Leszczyna Syncline (Leszczyna and Leszczyna-Kondratów) from the upper part of the Ca1, and 3 samples from the lower part of the Ca1 (mottled marls, Nowy Kościół). Eight samples were collected from the lower part of the Ca1 (unseparated equivalent of marl-limestone section of the Ca1 profile, between mottled-lead bearing marls) in the Lwówek Śląski Syncline (localities: Gościszów, Nawojów Śląski and Żarska Wieś; Fig. 1C).

Most of the investigated bryozoans are embedded in wellcemented matrix, but some samples expose large and well-preserved colonies on bedding planes that also allow to study of their external morphology. Internal morphology was studied in thin sections made from twenty-five oriented polished surfaces.

Some of the specimens were investigated using a Philips $X L-20$ SEM. These were coated with the pure platinum and imaged with secondary electrons. All specimens were examined with a Wild M10 binocular microscope equipped with planochromatic objective 1.0x. Measurements of all features (Tables 2-7) were made using an eyepiece micrometer affixed to the microscope. Five to thirty measurements of each feature were taken in most of the specimens.

Holotype and lectotype materials are deposited in the following institutions: Senckenberg Museum, Frankfurt; Paleontological Institute of the Academy of Sciences, Moscow; and Museum for Natural Sciences, Central Institute of the HumboldtUniversity, Berlin.

Described and illustrated material which derived from the samples of the numbers ING Uwr PR/Z/Bry/Ca1/1-41 is archived by the Wrocław University Museum, Institute of Geological Sciences. 

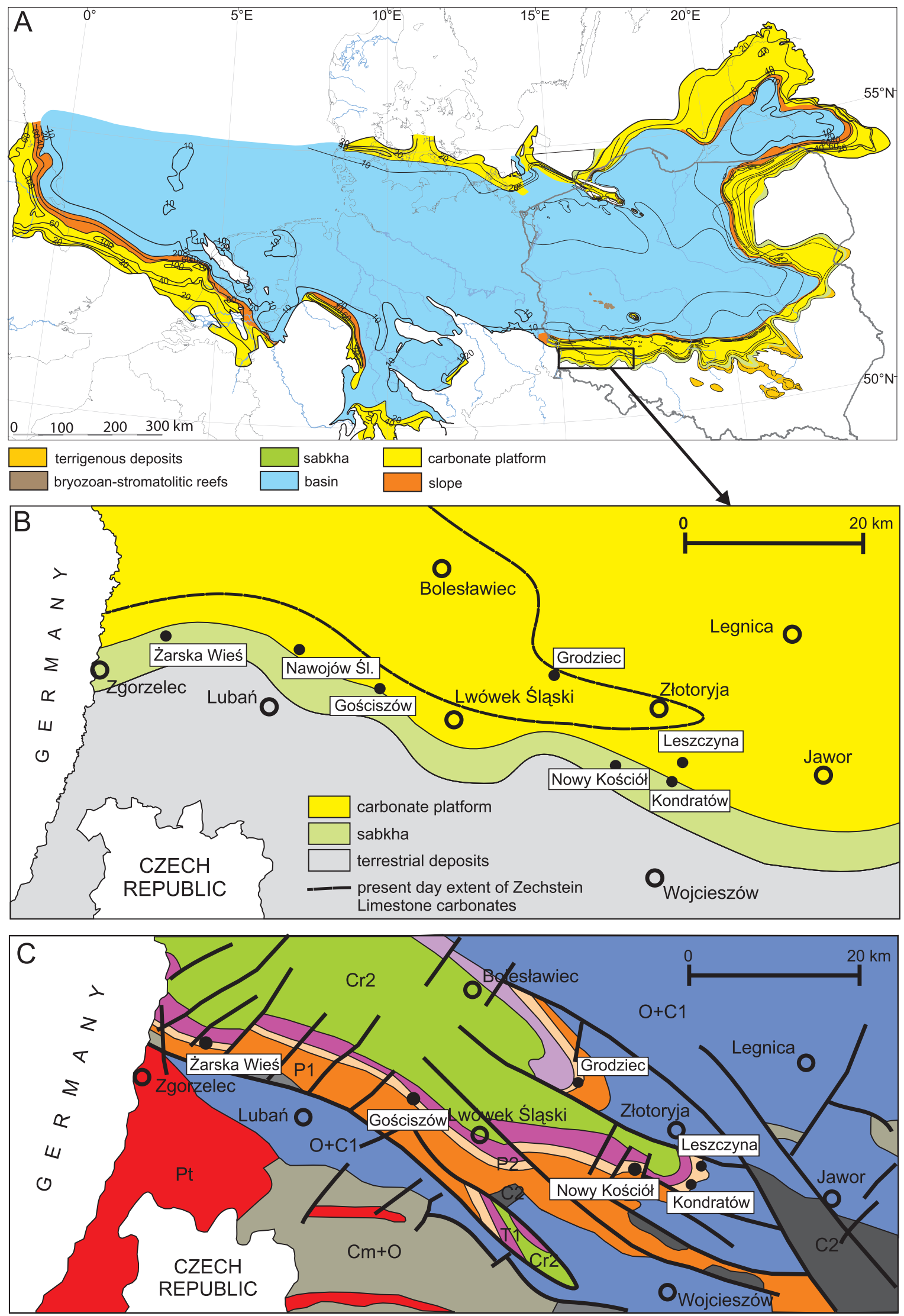

Fig. 1. Location (A) and a close-up view (B) of the study area: facies distribution of the Zechstein Limestone in the Southern Permian Basin (updated after Buniak et al., 2007; Peryt et al., 2010); C - simplified geological map of the North Sudetic Basin with the Zechstein Limestone sections studied (rectangles)

C - Pt - Proterozoic, Cm+O - Cambrian + Ordovician, O+C1 - Ordovician + Lower Carboniferous, C2 - Carboniferous, P1 - Lower Permian, P2 - Upper Permian (Zechstein), T1 - Lower Triassic, Cr2 - Upper Cretaceous; 
Lithostratigraphy of the Zechstein in the study area (modified after Raczyński, 2010)

\begin{tabular}{|c|c|c|c|c|c|}
\hline \multicolumn{4}{|c|}{ Lithostratigraphy } & \multirow[b]{2}{*}{ Lithology } & \multirow[b]{2}{*}{ Depostional environment } \\
\hline \multicolumn{2}{|c|}{$\begin{array}{l}\text { Zechstein } \\
\text { cycle }\end{array}$} & \multicolumn{2}{|c|}{ Local series } & & \\
\hline \multicolumn{2}{|c|}{$\mathrm{PZ} 4-\mathrm{PZt}$} & \multicolumn{2}{|c|}{ sandy-muddy-clayey series } & $\begin{array}{l}\text { red muddy sediments with thin beds of sandstone and clay; } \\
5-15 \mathrm{~m} \text { thick }\end{array}$ & $\begin{array}{l}\text { muddy lagoon, } \\
\text { coastal zone }\end{array}$ \\
\hline \multicolumn{2}{|c|}{ PZ 3} & \multicolumn{2}{|c|}{ Platy Dolomite } & $\begin{array}{l}\text { white and grey dolomite, micritic, granular and oolitic; } \\
2-12 \mathrm{~m} \text { thick }\end{array}$ & $\begin{array}{l}\text { shallow shelf, nearshore } \\
\text { carbonate platform }\end{array}$ \\
\hline \multirow{2}{*}{\multicolumn{2}{|c|}{ A1 }} & \multicolumn{2}{|c|}{ septarian shales } & $\begin{array}{l}\text { red clayey-muddy sediments with thin beds of sandstones and } \\
\text { limestone concretions; } 8-15 \text { m thick }\end{array}$ & $\begin{array}{l}\text { muddy lagoon, } \\
\text { coastal zone }\end{array}$ \\
\hline & & \multicolumn{2}{|c|}{ sandstones } & $\begin{array}{l}\text { red and yellow clayey-muddy sediments, with thin beds of } \\
\text { fine-grained sandstone; ripple cross-laminated sandstone; } \\
3-30 \text { m thick }\end{array}$ & $\begin{array}{l}\text { shallow water, } \\
\text { beach, coast }\end{array}$ \\
\hline \multirow{9}{*}{ PZ1 } & \multirow{8}{*}{ Ca1 } & \multirow{4}{*}{$\begin{array}{l}\text { massive } \\
\text { limestones } \\
\text { with } \\
\text { claystones }\end{array}$} & $\begin{array}{l}\text { sandy } \\
\text { limestones }\end{array}$ & $\begin{array}{l}\text { yellow and grey, thinly and medium bedded sandy limestone } \\
\text { and calcareous sandstone; } 6 \mathrm{~m} \text { thick }\end{array}$ & nearshore lagoon \\
\hline & & & $\begin{array}{l}\text { claystones with } \\
\text { limestones }\end{array}$ & $\begin{array}{c}\text { red and yellow clayey-muddy sediments with thin beds } \\
\text { of limestone; } 3 \mathrm{~m} \text { thick }\end{array}$ & $\begin{array}{l}\text { nearshore lagoon, } \\
\text { deeper part }\end{array}$ \\
\hline & & & $\begin{array}{l}\text { oolitic } \\
\text { limestones }\end{array}$ & $\begin{array}{l}\text { laminated light grey oolitic and oncolitic lime packstone and } \\
\text { grainstone, oncoids }<0.5 \mathrm{~cm} \text { in diameter in the upper part, } \\
\text { lower part contains ooids, carbonate intraclasts, laminae } \\
\text { composed of quartz grains also occur, planar and cross- } \\
\text { bedding, bioclasts (bivalves, gastropods); } 1.5 \mathrm{~m} \text { thick }\end{array}$ & nearshore oolitic shoal \\
\hline & & & $\begin{array}{l}\text { massive } \\
\text { limestones }\end{array}$ & $\begin{array}{l}\text { sandy limestone, horizontally and hummocky-crossed } \\
\text { stratified, bioclastic packstone: abundant foraminifera, brachio- } \\
\text { pods, echinoids, bryozoans (in the middle part: fragments of } \\
\text { Acanthocladia and fenestellids) and bivalves, bioclasts are } \\
\text { represented predominantly by a Bakevellia, Schizodus and } \\
\text { Permophorus assemblage, tempestites; } 6 \text { m thick }\end{array}$ & $\begin{array}{l}\text { proximal tempestite, } \\
\text { shallow water: between } \\
\text { normal and storm wave } \\
\text { base (HCS - hummocky } \\
\text { cross-stratification) and } \\
\text { above normal wave base }\end{array}$ \\
\hline & & \multicolumn{2}{|c|}{ lead-bearing marls } & $\begin{array}{l}\text { grey marly lime mudstone with intercalations of dark marls, } \\
\text { passing upward into sandy limestone which are horizontally } \\
\text { and hummocky-cross stratified; in general, the fauna is repre- } \\
\text { sented by abundant foraminifera, brachiopods, echinoids, } \\
\text { bryozoans (Dyscritella, Acanthocladia, Spinofenestella), and } \\
\text { bivalves (Bakevellia, Permophorus), some fossils are mineral- } \\
\text { ized with copper, lead and/or zinc sulphides; } 2.8 \text { m thick }\end{array}$ & $\begin{array}{l}\text { distal tempestite } \\
\text { (limestone, marls), shelf } \\
\text { (mudstone); below storm } \\
\text { wave base }\end{array}$ \\
\hline & & \multicolumn{2}{|c|}{ copper-bearing marls } & $\begin{array}{c}\text { grey and dark grey clayey marls and marly limestones, rare } \\
\text { bioclasts of bivalves Bakevellia and Permophorus, bryozoans } \\
\text { (Dyscritella, Acanthocladia) and brachiopods all commonly } \\
\text { mineralized with copper sulphides; } 1.5 \mathrm{~m} \text { thick }\end{array}$ & $\begin{array}{l}\text { distal tempestite } \\
\text { (limestone, marls), } \\
\text { shelf (mudstone); } \\
\text { below storm wave base }\end{array}$ \\
\hline & & \multicolumn{2}{|c|}{ mottled marls } & $\begin{array}{c}\text { dark grey marls and limestones, mottling associated with red } \\
\text { patches (up to } 40 \% \text { of total bed thickness), coquinas: brachio- } \\
\text { pods, bryozoans (in the lower part: Dyscritella, Kingopora, } \\
\text { Kalvariella, Acanthocladia, ostracods, gastropods, } \\
\text { foraminifara and bivalves such as Bakevellia, Schizodus and } \\
\text { Permophorus; in upper part 0.4m lime packstones rich in } \\
\text { Horridonia, bryozoans: Spinofenestella, Kingopora; } \\
0.5 \mathrm{~m} \text { thick; thickness of the horizon < < m }\end{array}$ & $\begin{array}{l}\text { open shelf; below storm } \\
\text { wave base } \\
\text { distal tempestite } \\
\text { (limestone, marls), } \\
\text { shelf (mudstone); } \\
\text { below storm wave base }\end{array}$ \\
\hline & & \multicolumn{2}{|c|}{ basal limestone } & $\begin{array}{l}\text { grey and purple lime mudstone, medium and thickly bedded, } \\
\text { massive, rare fossils, horizontal and wavy bedding, locally } \\
\text { interbedded with oolitic limestone; }<1 \mathrm{~m} \text { thick }\end{array}$ & closed lagoon \\
\hline & \multicolumn{3}{|c|}{ S1 } & $\begin{array}{l}\text { pink and grey polymictic conglomerate, medium and thickly } \\
\text { bedded, rare sandstone and conglomerate sandstone with } \\
\text { fossils, indistinct normal and parallel bedding, locally in con- } \\
\text { glomerates are pebbles of quartz, porphyry and schists; } \\
1 \mathrm{~m} \text { thick }\end{array}$ & $\begin{array}{l}\text { Rotliegend conglomerates } \\
\text { reworked during } \\
\text { transgression } \\
\text { of the Zechstein Sea }\end{array}$ \\
\hline \multicolumn{4}{|c|}{ Upper Rotliegend } & $\begin{array}{c}\text { red and pink polymictic conglomerate, medium and thickly } \\
\text { bedded, indistinct normal and parallel bedding, pebbles of } \\
\text { quartz, porphyry and schists, locally carbonate cementation } \\
\text { caliche-type; }>10 \mathrm{~m} \text { thick }\end{array}$ & fluvial, alluvial fan \\
\hline
\end{tabular}

Informal subunit of massive limestones and claystones is proposed herein as a substitute for Middle Zechstein limestones; PZ 1, 3, 4 Zechstein cycle 1, 3, 4; A1 - Werra Anhydrite; Ca1 - Zechstein Limestone, S1 - basal conglomerate, PZt - transitional series

\section{SYSTEMATIC DESCRIPTIONS}

Phylum BRYOZOA Ehrenberg, 1831

Class STENOLAEMATA Borg, 1926

Order TREPOSTOMIDA Ulrich, 1882

Family DYSCRITELLIDAE Dunaeva and Morozova, 1967

Dyscritella Girty, 1911
Type species: Dyscritella robusta Girty, 1911; Lower Carboniferous; North America

D i a g n o s i s. - Dendroid and encrusting colonies with abundant acanthostyles and exilazooecia. Autozooecia parallel to longitudinal direction of the colony in endozone; gradually arching outwardly in exozone. Diaphragms in autozooecia absent or very rare; absent in exilazooecia. Exilazooecia circular to angular in cross-section and separated from the autozooecia 


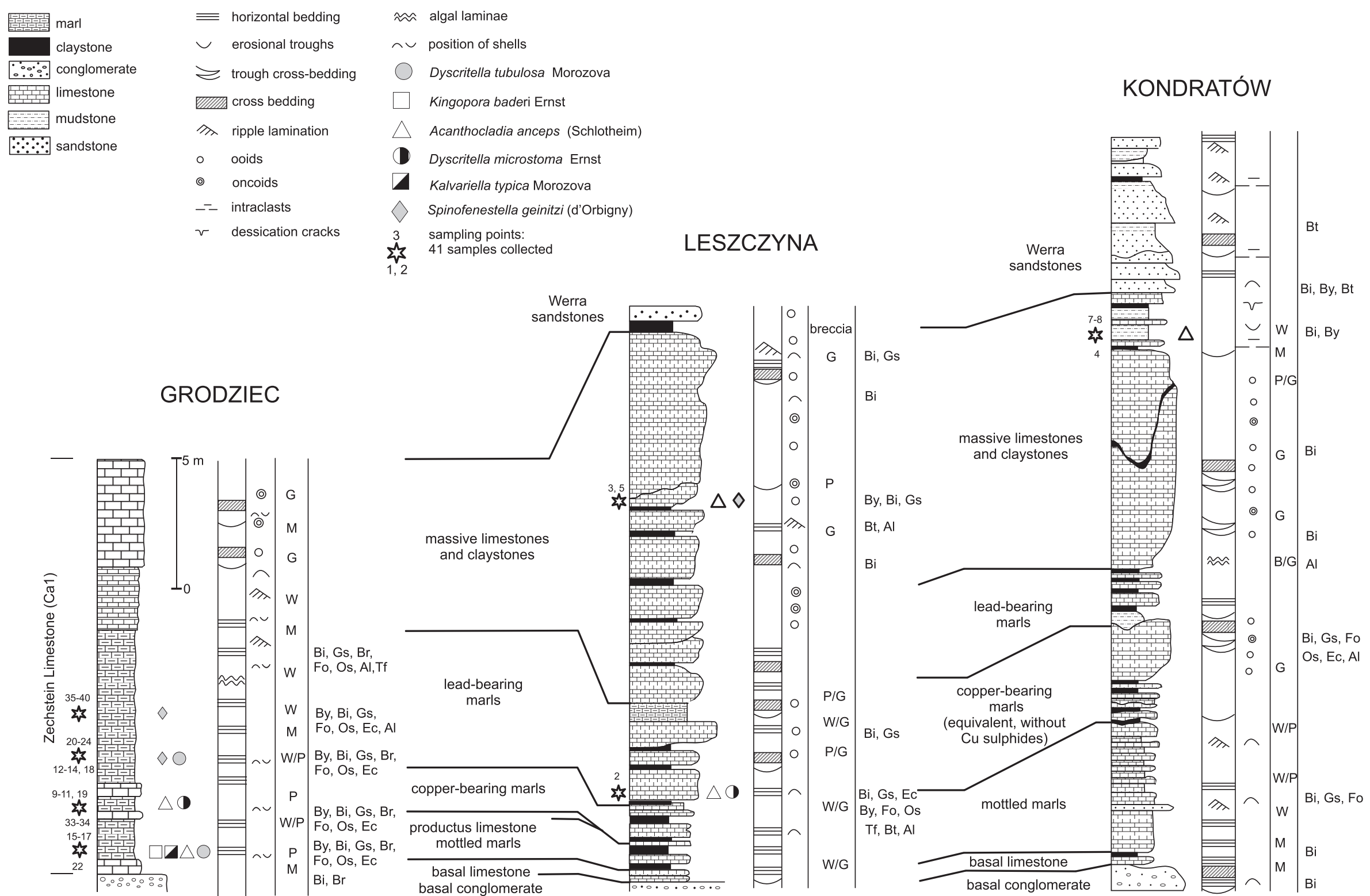


and from each other by thick walls. Two sizes of acanthostyles may be present: large with few per autozooecia, and small with several around each autozooecium. Zooecial walls thin in endozone, rapidly thickening in the exozone.

C o m p a r i s o n. - Dyscritella Girty, 1911 differs from Dyscritellina Morozova, 1967 by the rarity or absence of diaphragms and less differentiated acanthostyles. an.

O c c u r r e n c e. - Carboniferous to Triassic; cosmopoli-

\section{Dyscritella tubulosa Morozova, 1970 \\ Figs. 4A-F, 9A and Table 2}

1970 Dyscritella tubulosa Morozova - Morozova (1970), p. 121, pl. 19, fig. 1. 2001 Dyscritella tubulosa Morozova, 1970 - Ernst (2001a), p. 139, pl. 1, figs. 1, 2.

H o l o t y p e. - No. 2343/122; Paleontological Institute of the Academy of Sciences, Moscow; Upper Permian, Zechstein; Lithuania.

M a t e rial e x a m i n e d. - Grodziec (Grodziec Syncline) samples numbered ING UWrPR/Z/Bry/Ca1/15, 24 and Lwówek Śląski Syncline ING UWrPR/Z/Bry/Ca1/30; thin-sections of the samples ING UWrPR/Z/Bry/Ca1/15, 24

D e s c ri p t i o n. - Encrusting colonies, $0.48-0.66 \mathrm{~mm}$ thick. Autozooecial apertures polygonal, $7-9$ per $2 \mathrm{~mm}$ (in each direction) and 12-18 apertures per $1 \mathrm{~mm}^{2}$ at the colony surface. Diaphragms absent both in autozooecia and exilazooecia. Walls in the endozone $0.01-0.015 \mathrm{~mm}$ thick, fibrous, in the exozone $0.02-0.04 \mathrm{~mm}$ thick and obliquely laminated. Acanthostyles large, abundant, with distinct calcite cores. Cores are $0.015-0.025 \mathrm{~mm}$ in diameter and run throughout the exozone. Usually 1-5 acanthostyles surround each autozooecial aperture, 18-40 spaced per $1 \mathrm{~mm}^{2}$ at colony surface, often inflecting into the autozooecia. Exilazooecia short, polygonal in cross-section, rare, or absent. Maculae consisting of larger autozooecia.

C o $\mathrm{m} \mathrm{p}$ a r i s o n. - Discritella tubulosa is closely related to D. incrustata Morozova, 1970 and D. microstoma Ernst, 2001. It differs from D. incrustata (Morozova, 1970) by the smaller and weakly differentiated acanthostyles in the latter, and from $D$. microstoma which has larger and more loosely arranged apertures and fewer acanthostyles.

O c c u r r e n c e. - Ca1, Upper Permian, Grodziec and Lwówek Ślaski syneclises, North Sudetic Basin, SW Poland; Thuringia (Germany; Ernst, 2001a) and Lithuania (Morozova, 1970).

\section{Dyscritella microstoma Ernst, 2001}

Figs. 3, 4G-I, 9B and Table 3

2001 Dyscritella microstoma Ernst - Ernst (2001a), p. 139, pl. 1, figs. 3-5

H o l o t y p e. - SMF 1601; Senckenberg Museum, Frankfurt (Main)

Material examined. - Grodziec (Grodziec Syncline) samples numbered ING UWrPR/Z/Bry/Ca1/11, 19, 23 and Lwówek Ślaski Syncline samples ING UwrPR/Z/Bry/Ca1/25, and Nowy Kościół samples ING UWrPR/Z/Bry/Ca1/41; the thin sections of the samples ING UWrPR/Z/Bry/Ca1/19, 23, 41.

$\mathrm{D}$ e s c r i p t i o n. - Encrusting colonies 0.24 to $0.31 \mathrm{~mm}$ thick. Autozooecial apertures polygonal in cross-section, 7-12 apertures per $2 \mathrm{~mm}$ (in each direction) and 21-27 apertures in $1 \mathrm{~mm}^{2}$ at colony surface. Walls in the endozone $0.01 \mathrm{~mm}$ thick and structureless, in the exozone $0.01-0.025 \mathrm{~mm}$ thick and obliquely laminated. Exilazooecia polygonal in cross-section, rare, or absent. Diaphragms in autozooecia rare. Acanthostyles large, abundant, with distinct, $0.01-0.025 \mathrm{~mm}$ wide calcite

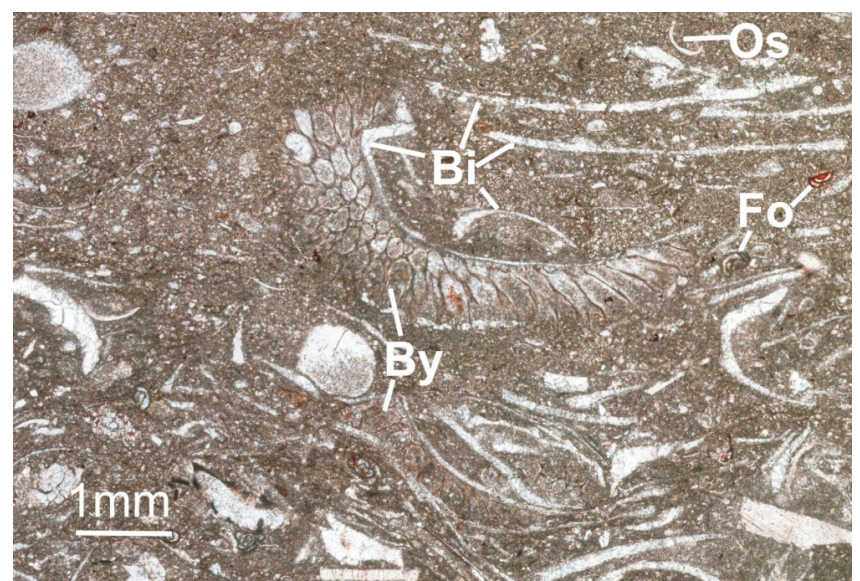

Fig. 3. Bioclastic packstone (distal tempestites) showing an association of the Dyscritella bryozoan colony (By) encrusting bivalve shells (Bi), ostracods (Os), and foraminifers (Fo); mottled marls, ING UWr/PR/Z/Bry/Ca1/41, Leszczyna Syncline, North Sudetic Basin

cores in cross-section, 50-52 spaced per $1 \mathrm{~mm}^{2}$ on colony surface, often deeply inflecting autozooecia. Acanthostyle cores present throughout the exozone, 4-7 acanthostyles surround each aperture.

C o m p a r i s o n. - Dyscritella microstoma Ernst, 2001 differs from $D$. tubulosa in having smaller autozooecia, thinner walls as well as smaller and more abundant acanthostyles.

O c c u r r e n c e. - Ca1, Upper Permian, Grodziec (lower and upper part of Ca1), Lwówek Śląski synclines (lower part of Ca1), Leszczyna Syncline (lower part of Ca1), North Sudetic Basin, SW Poland. This species was originally described from the Ca1 of Germany (Ernst, 2001a). Dyscritella microstoma has been recorded from the Zechstein Main Dolomite (Ca2) in the NE part of Germany (Rugen Island) and the western and northern parts of Poland (Pogorzela 2 well, Fore-Sudetic Monocline; as well as Unisław IG 2 in Pomerania; Hara et al., 2009). Recorded also from Thuringia and Hessen and Lithuania (Germany; Ernst, 2001a).

Order FENESTELLIDA Astrova and Morozova, 1956

Suborder FENESTELLINA Astrova and Morozova, 1956 Family Acanthocladiidae Zittel, 1880 Kingopora Morozova, 1970

Type species: Gorgonia ehrenbergi Geinitz 1846, Upper Permian, Zechstein, Thuringia

C o m p a ri s o n. - Kingopora differs from Reteporidra Nickles and Bassler, 1900 in having fewer rows of autozooecia on the branches joining through anastomoses rather than by dissepiments.

Occurrence. - Lower Permian of the Arctic $[K$. micropora (Stuckenberg, 1895), K. exigua Krutchinina, 1986 in Morozova and Krutchinina, 1986]; Middle Permian (Kazanian) of the Russian Plate K. parvifenestrata Morozova, 1970; Upper Permian of North America, Germany and England [K. ehrenbergi (Geinitz, 1861)].

Kingopora baderi Ernst, 2001

Figs. 4J-M, 5A, 6 and Table 4

2001 Kingopora baderi Ernst - Ernst (2001a), p. 144, pl. 4, fig. 6, pl. 5, figs. 1-4. 

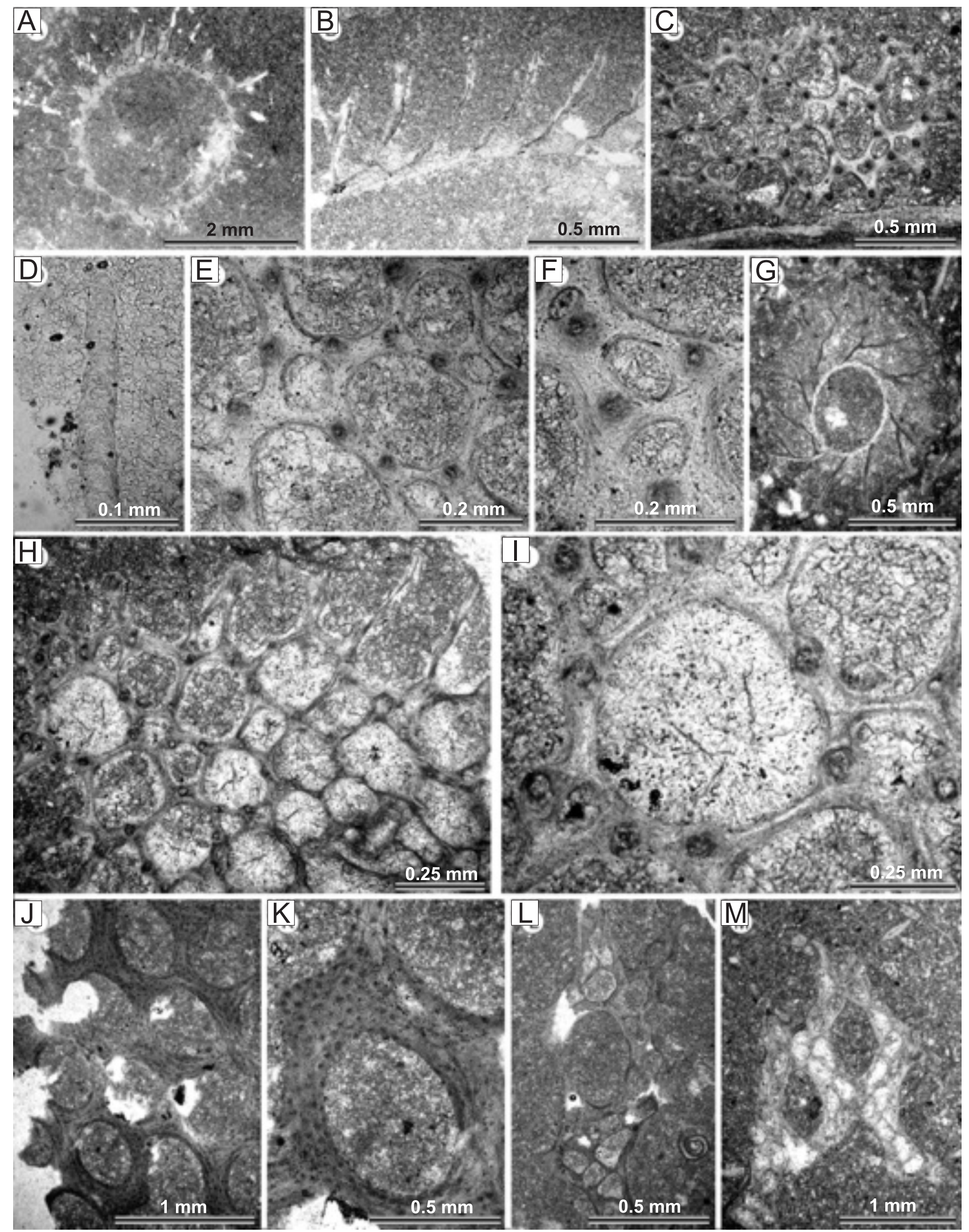

Fig. 4A-F - Dyscritella tubulosa Morozova, 1970 (A - cross-section of the tubular colony; B - longitudinal section of the colony; C tangential section of the colony; D - longitudinal section of the colony displaying wall structure in exozone; $\mathrm{E}$, F-tangential section of the colony, displaying autozooecial apertures, acanthostyles and exilazooecia; A, B, D - specimen ING UWr PR/Z/Bry/Ca1/24, lead-bearing marls; C, E, F - specimen ING UWr/PR/Z/Bry/Ca1/15, mottled marls); G-I - Dyscritella microstoma Ernst, 2001 (G - cross-section of an encrusting colony; H, I - tangential section of the colony; G-I specimen ING UWrPR/Z/Bry/Ca1/19, lower part of the Ca1, copper-bearing marls); J-M - Kingopora baderi Ernst, 2001 (J-reverse side of the colony; $\mathrm{K}$ - reverse side of the colony, displaying microacanthostyles; $\mathrm{L}, \mathrm{M}$ - tangential section of the colony displaying apertures and autozooecial chambers; J-M - specimen ING UWr PR/Z/Bry/Ca1/15, mottled marls); A-M - Grodziec (Grodziec Syncline) 

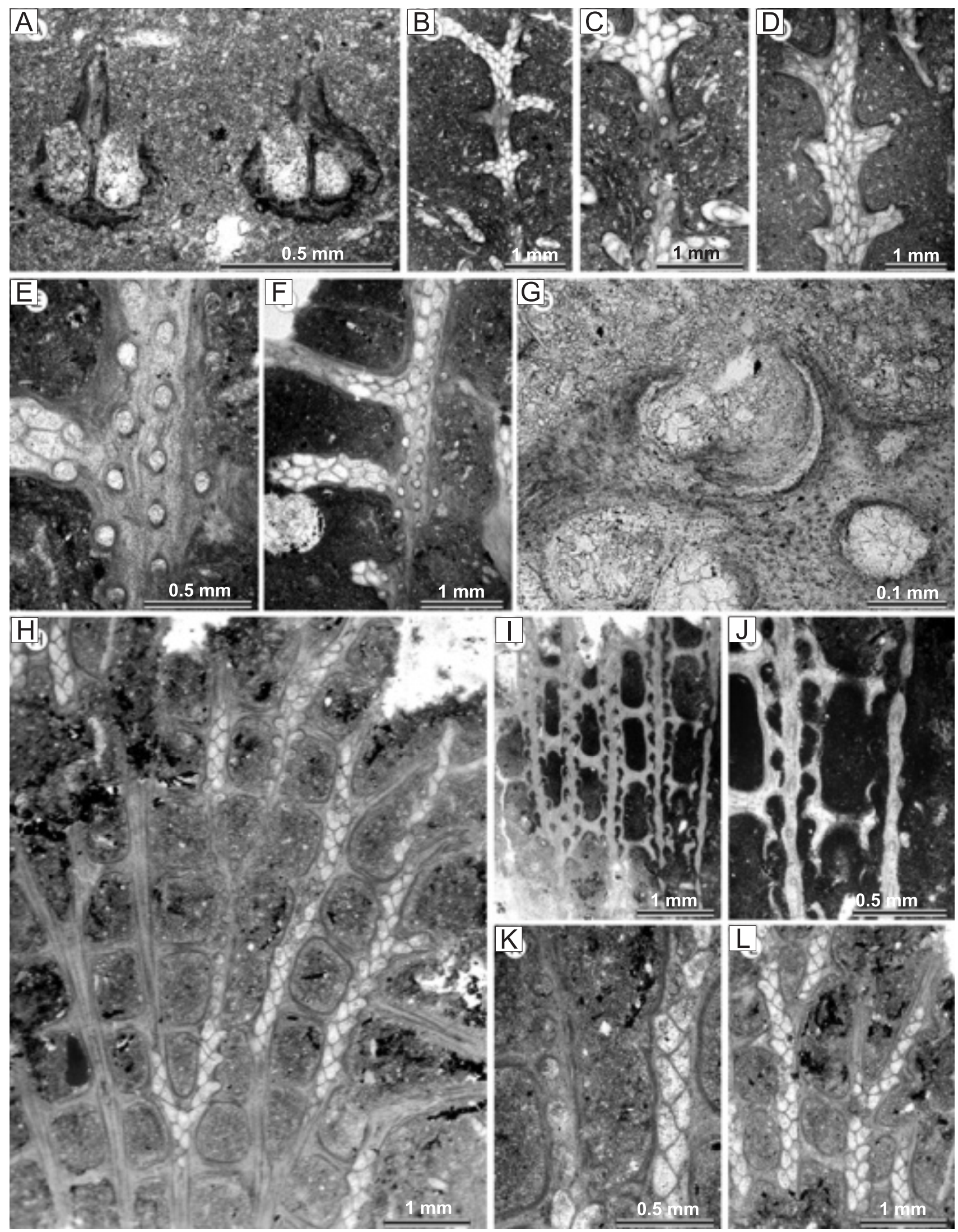

Fig. 5A - Kingopora baderi Ernst, 2001, cross-section of the branches; B, C - Kalvariella typica Morozova, 1970, tangential thin section of the branch; D-G - Acanthocladia anceps (Schlotheim, 1820) (D - deep tangential section of the branch; A-D - specimen ING UWr/PR/Z/Bry/Ca1/15, mottled marls; E - tangential section of the branch; F - tangential section of the branch; $E$, F specimen ING UWr PR/Z/Bry/Ca1/38, copper-bearing marls; G - polymorph zooid with ovicell chamber, specimen ING UWr/PR/Z/Bry/Ca1/15, mottled marls); H-L - Spinofenestella geinitzi (d'Orbigny, 1850) (H - fragment of the colony, tangential thin section; I, J - tangential thin section, specimen ING UWr PR/Z/Bry/Ca1/13, lower part of the lead-bearing marls; $K, L$ - tangential thin section; H, K, L - specimen ING UWr PR/Z/Bry/Ca1/24, lead-bearing marls); A-L - Grodziec (Grodziec Syncline) 

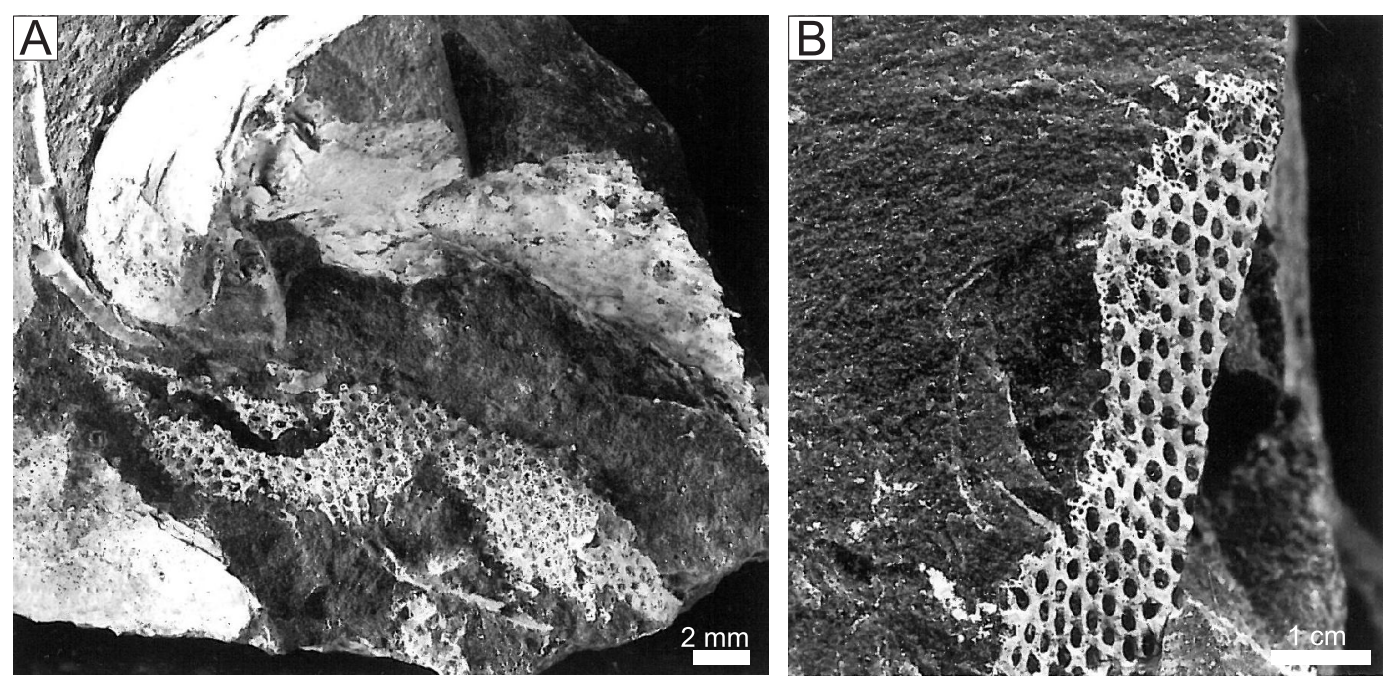

Fig. 6A - Kingopora baderi Ernst; A - part of the funnel-shaped reteporiform colony embedded into a sediment in the interior of the large brachiopod shell of Horridonia horrida (Sowerby), ING UWr/PR/Z/Ca-1/Bry/30, Żarska Wieś, Lwówek Śląski Syncline; B - part of the retiform colony, showing the oval fenestrules, ING UWr/PR/Z/Ca1/Bry/15, mottled marls (Grodziec, Grodziec Syncline)

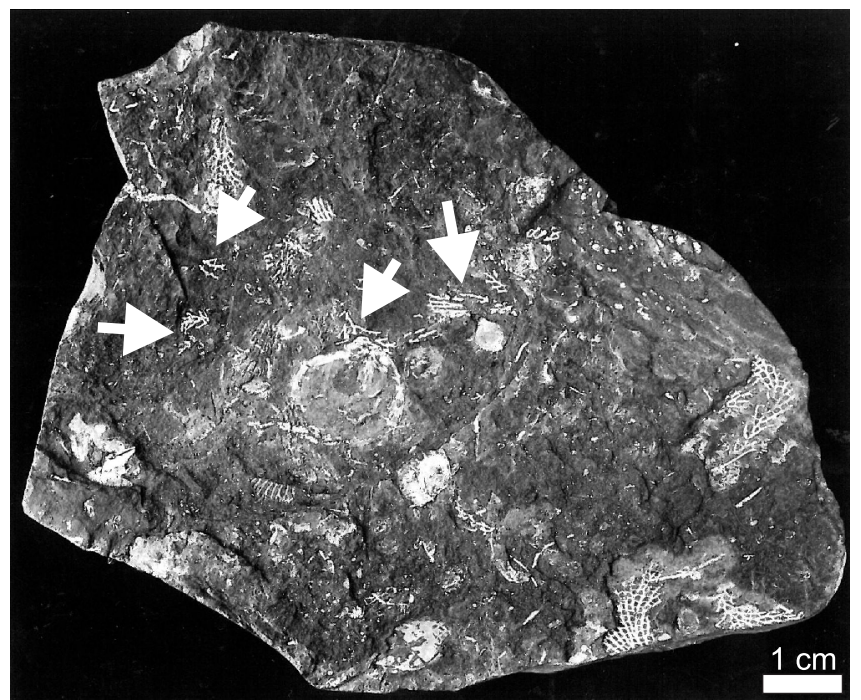

Fig. 7. Weathered fracture in the dark, lead-bearing marls showing the broken reticulated zoaria of Spinofenestella geinitzi (d'Orbigny), accompanied by small fragmented branches of acanthocladiids (arrows), ING UWr/PR/Z/Ca1/Bry/23, lead-bearing horizon (Grodziec, Grodziec Syncline) kfurt.

H o l o t y p e. - SMF 1609b; Senckenberg Museum, Fran-

M a t e ri a I e x a m i n e d. - Grodziec (Grodziec Syncline), Zechstein Limestone: sample ING UWrPR/Z/Bry/Ca-1/15; a thin section of the sample ING UWrPR/Z/Bry/Ca1/15, mottled marls.

De s c ription. - Small funnel-shaped colony up to $2 \mathrm{~cm}$ high. Apertures open on outer side of the colony surface. Branches undulose and joined mostly by dissepiments, oval shaped in cross-section. Fenestrules oval and often extremely narrow. Autozooecia arranged in 2, 3 rows on the branches, the third row usually developed proximal to bifurcations. Dissepiments usually without autozooecia. Autozooecial apertures 3, 4 per fenestrule length, circular to oval with low peristomes. Low keel with long spines between apertures. Microacanthostyles irregularly spaced over the entire surface of the colony,

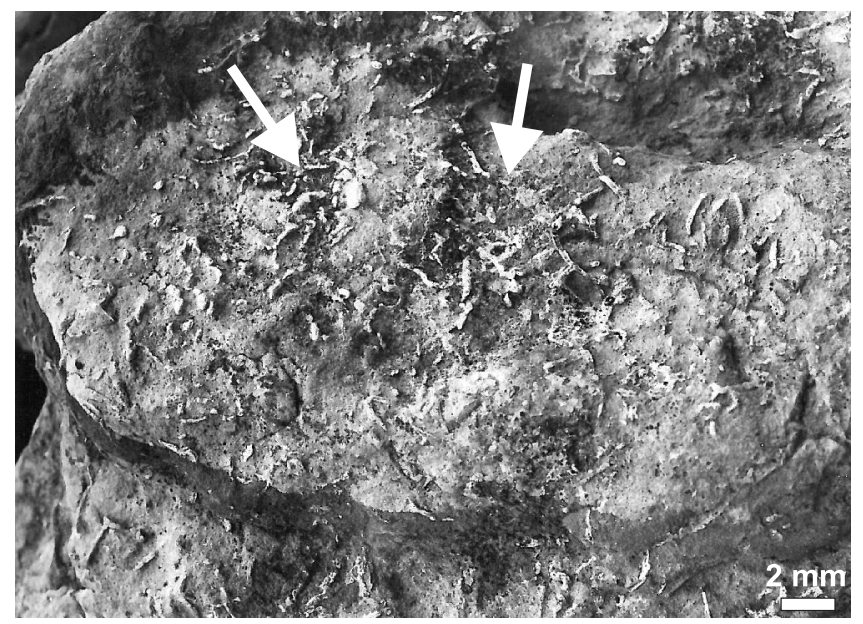

Fig. 8. A weathered top surface of sandy limestones with the broken fragments of the numerous colonies of Acanthocladia anceps (arrows), accompanied by a few zoaria of fenestellids, ING UWr/PR/Z/Ca1/Bry/3, upper part of the Ca1 (Leszczyna, Leszczyna Syncline)

$0.015-0.035 \mathrm{~mm}$ in diameter, growing from the granular layer and passing through the outer laminar skeleton to the colony surface. Outer laminar skeleton weakly developed.

Interior description. - Autozooecia box-shaped, short, high, having polygonal shape in the mid tangential section, elongate parallel to branch length; aperture positioned at distal to distal-abaxial end of chamber. Vestibule usually short. Both superior and inferior hemisepta absent.

C o $\mathrm{m} \mathrm{p}$ a r i s o $\mathrm{n}$. - This species differs from all species of the genus Kingopora in the closely spaced autozooecia in two rows on the branches, smaller dimensions of the colony and long spines on the keel.

O c c u r r e n c e. - Ca1, Upper Permian, Grodziec (Grodziec Syncline), North Sudetic Basin, SW Poland. Recorded from the bedded facies of the Zechstein Limestone of Thuringia and Lower Saxony (Germany) (Ernst, 2001a). 

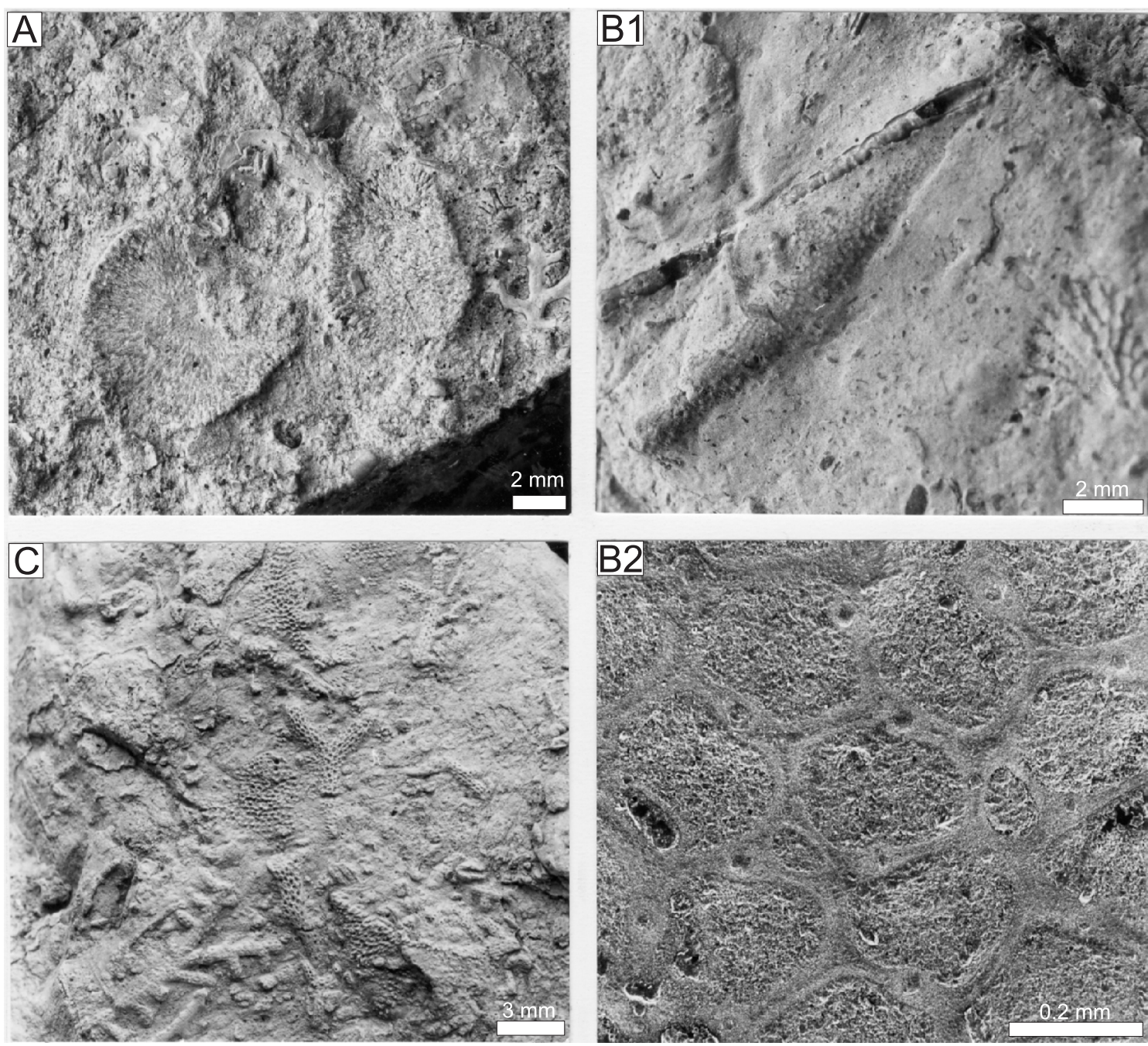

Fig. 9A - cup-shaped colonies of the genus Dyscritella tubulosa Morozova, with the accompanying colony of acanthocladiid on the right; in the background the shelly remains of the brachiopods are seem, lower part of the Ca1, ING UWr/PR/Z/Ca1/Bry/30, Żarska Wieś (Lwówek Śląski Syncline); B1 - encrusting colony of the Dyscritella microstoma Ernst overgrowing the long spines of a brachiopod of Horridonia horrida (Sowerby); B2 - SEM image of the zoarial surface of the same colony showing the irregularly-shaped polygonal autozooecia surrounded by 1 to 5 acanthostyles, ING UWr/PR/Z/Ca1/Bry/11, lower part of the Ca1 (copper-bearing marls), Grodziec (Grodziec Syncline); C - broken colonies of the Acanthocladia anceps showing mostly the distal parts of the colonies resting on the substratum, ING UWr/PR/Z/Ca1/Bry/31, Żarska Wieś, lower part of the Ca1 (Lwówek Śląski Syncline)

Table 2

Measurements of Dyscritella tubulosa Morozova (two colonies)

\begin{tabular}{|l|c|c|c|c|c|c|}
\hline & $\mathrm{N}$ & $\mathrm{X}$ & $\mathrm{SD}$ & $\mathrm{CV}$ & $\mathrm{MIN}$ & $\mathrm{MAX}$ \\
\hline $\begin{array}{l}\text { Aperture } \\
\text { width }\end{array}$ & 29 & 0.202 & 0.0215 & 10.6624 & 0.168 & 0.240 \\
\hline $\begin{array}{l}\text { Acanthostyle } \\
\text { diameter }\end{array}$ & 30 & 0.045 & 0.0051 & 11.1930 & 0.035 & 0.055 \\
\hline $\begin{array}{l}\text { Exilazooecia } \\
\text { width }\end{array}$ & 16 & 0.060 & 0.0244 & 40.7113 & 0.025 & 0.125 \\
\hline $\begin{array}{l}\text { Acanthostyles } \\
\text { per aperture }\end{array}$ & 25 & 3.440 & 1.1576 & 33.6507 & 1.000 & 5.000 \\
\hline $\begin{array}{l}\text { Exozonal wall } \\
\text { thickness }\end{array}$ & 10 & 0.028 & 0.0071 & 25.0477 & 0.020 & 0.040 \\
\hline
\end{tabular}

$\mathrm{N}$ - total number of measurements, $\mathrm{X}$ - arithmetic mean, SD - standard deviation, $\mathrm{CV}$ - coefficient of variance, MIN - smallest measurement, MAX - largest measurement; measurements in $\mathrm{mm}$, except for quantitative parameters
Subfamily Acanthocladiinae Zittel, 1880 Kalvariella Morozova, 1970

1930 Pinnatopora waltheri (pars Korn) - Korn (1930), p. 371, 372 [partim] 1970 Kalvariella Morozova - Morozova (1970), p. 242 2001 Kalvariella Morozova, 1970 - Ernst (2001a), p. 145, 146 2001 Kalvariella Morozova, 1970 - Morozova (2001), p. 78, 79

T y p e s p e c i e s. - Kalvariella typica Morozova, 1970. Upper Permian, Lithuania.

D i a g n o s i s. - Colonies containing main branches and secondary branches. Autozooecia arranged in two rows on the main branch and in 3-4 rows on secondary branches. Keel on the main branch (Morozova, 1970).

C o m p a r i s o n. - Kalvariella differs from Acanthocladia in having two rows of autozooecia on the main branches.

O c c u r e n c e. - Upper Permian, Zechstein of Germany, England, Poland. 
Table 3

Measurements of Dyscritella microstoma Ernst (three colonies)

\begin{tabular}{|l|c|c|c|c|c|c|}
\hline & $\mathrm{N}$ & $\mathrm{X}$ & $\mathrm{SD}$ & $\mathrm{CV}$ & $\mathrm{MIN}$ & $\mathrm{MAX}$ \\
\hline $\begin{array}{l}\text { Aperture } \\
\text { width }\end{array}$ & 15 & 0.167 & 0.0270 & 16.1550 & 0.120 & 0.204 \\
\hline $\begin{array}{l}\text { Acanthostyle } \\
\text { diameter }\end{array}$ & 15 & 0.043 & 0.0096 & 22.3235 & 0.030 & 0.055 \\
\hline $\begin{array}{l}\text { Exilazooecia } \\
\text { width }\end{array}$ & 10 & 0.055 & 0.0151 & 27.4406 & 0.035 & 0.075 \\
\hline $\begin{array}{l}\text { Acanthostyles } \\
\text { per aperture }\end{array}$ & 10 & 5.500 & 0.8498 & 15.4516 & 4.000 & 7.000 \\
\hline $\begin{array}{l}\text { Exozonal wall } \\
\text { thickness }\end{array}$ & 10 & 0.019 & 0.0047 & 25.6401 & 0.010 & 0.025 \\
\hline
\end{tabular}

For explanations see Table 2

\section{Kalvariella typica Morozova, 1970 Fig. 5B, C and Table 5}

1930 Pinnatopora waltheri (pars) Korn - Korn (1930), p. 372, 373, pl. 35, fig. 18. 1970 Kalvariella typica Morozova, 1970 - Morozova (1970), p. 242, 243, pl. 58, fig. 6 .

2001 Kalvariella typica Morozova, 1970 - Ernst (2001a), p. 146, pl. 6, figs. 1-4.

H o I o t y p e. - 2343/7; Paleontological Institute, Moscow. Upper Permian, Zechstein, Lithuania.

M a t e r i a I s t u d i e d. - Grodziec (Grodziec Syncline), single specimen in the sample numbered ING UWrP-R/Z/Bry/Ca1/15, mottled marls.

D e s c r i p t i o n. - Pinnate colony consisting of straight main branch with secondary branches. Main branch 0.44-0.49 $\mathrm{mm}$ wide, secondary branches $0.36-0.54 \mathrm{~mm}$ wide, diverging at angles of $63-86^{\circ}$ (average $76.8^{\circ}$ ) from the main branch, 3-4 spaced per $5 \mathrm{~mm}$ along the main branch on each side. Autozooecia arranged on the main branch in two and on the secondary branches in 3-4 rows. Apertures circular to oval, 18 spaced per $5 \mathrm{~mm}$ of the branch length. Wide keel with small elliptical nodes between the rows of autozooecial apertures on the main branch. Abundant microstyles, 0.005-0.015 mm in di- ameter, regularly spaced at distances of 0.005-0.02 mm. Polymorphs comprising inferred brooding zooids with ovicells at the distal end of the vestibule. The ovicells are $0.18-0.216 \mathrm{~mm}$ in diameter.

I n t e ri or d e s c r i p t i o n. - Autozooecia rectangular on the main branch and hexagonal on the secondary branches in mid tangential section; elongate parallel to branch length; aperture positioned at distal to distal-abaxial end of chamber. Superior hemisepta weakly developed; interior hemisepta absent.

O c c u r r e n c e. - Zechstein Limestone, Upper Permian, Grodziec (Grodziec Syncline), North Sudetic Basin, SW Poland. Recorded by Ernst (2001a) from the Zechstein of Germany, as well as from England and Lithuania (Morozova, 2001).

\section{Acanthocladia King, 1849}

1850 Acanthocladia King, 1849, p. 48.

1861 Acanthocladia King, 1849 - Geinitz (1861), p. 119

1930 Acanthocladia King, 1849 - Korn (1930), p. 369.

1930 Thamniscus King, 1849 - Korn (1930), p. 364, 365 [partim]

1961 Acanthocladia King, 1849 - Dreyer (1961), p. 21, 22.

1970 Acanthocladia King, 1849 - Morozova (1970), p. 239.

2001 Acanthocladia King, 1849 - Ernst (2001a), p. 146

2001 Acanthocladia King, 1849 - Morozova (2001), 77, 78.

Ty p e s p e c i e s. - Keratophytes anceps Schlotheim 1820; Upper Permian, Thuringia, Glücksbrunn.

D i a g n o s i s. - Colonies consisting of main branches with secondary branches. Autozooecia arranged in three or more rows both on main and secondary branches, rectangular to hexagonal in mid tangential section. Superior hemisepta weakly developed; inferior hemisepta absent. Apparent reproductive polymorphs in form of isolated zooecia with enlarged proximal endozonal chambers are common.

O c c u r r e n c e. - Upper Permian, lower part of the Ca1 (reefal facies) in Germany, England, Poland, Lithuania and Russia.

Acanthocladia anceps (Schlotheim, 1820)

Figs. 5D-G, 8, 9C and Table 6

1820 Keratophytes anceps Schlotheim - Schlotheim (1820), p.341, 342. 1848 Fenestella anceps (Schlotheim 1820) - Geinitz (1848), p. 18, pl. 7, figs. 22 , 23, [non figs. 19-21].

Measurements of Kingopora baderi Ernst (two colonies)

\begin{tabular}{|l|r|r|r|r|r|c|}
\hline & $\mathrm{N}$ & $\mathrm{X}$ & $\mathrm{SD}$ & $\mathrm{CV}$ & $\mathrm{MIN}$ & $\mathrm{MAX}$ \\
\hline Branch width & 10 & 0.295 & 0.0434 & 14.7025 & 0.240 & 0.350 \\
\hline Dissepiment width & 8 & 0.378 & 0.0740 & 19.5696 & 0.276 & 0.528 \\
\hline Fenestrule length & 10 & 0.611 & 0.0384 & 6.2909 & 0.550 & 0.690 \\
\hline Fenestrule width & 10 & 0.409 & 0.0618 & 15.1089 & 0.336 & 0.528 \\
\hline Distance between dissepiment centres & 10 & 0.918 & 0.0839 & 9.1399 & 0.780 & 1.020 \\
\hline Distance between branch centres & 10 & 0.705 & 0.0495 & 7.0209 & 0.600 & 0.750 \\
\hline Aperture width & 7 & 0.103 & 0.0117 & 11.3855 & 0.084 & 0.120 \\
\hline Node diameter & 10 & 0.070 & 0.0113 & 16.1416 & 0.054 & 0.084 \\
\hline Distance between node centres & 6 & 0.354 & 0.0367 & 10.3684 & 0.310 & 0.420 \\
\hline Autozooecial chamber depth & 7 & 0.168 & 0.0227 & 13.5029 & 0.130 & 0.200 \\
\hline Branch thickness & 10 & 0.324 & 0.0310 & 9.5547 & 0.290 & 0.360 \\
\hline Maximal autozooecial chamber width & 10 & 0.129 & 0.0095 & 7.3541 & 0.120 & 0.144 \\
\hline Vestibule length & 5 & 0.132 & 0.0306 & 23.1774 & 0.096 & 0.180 \\
\hline Microacanthostyle diameter & 10 & 0.025 & 0.0058 & 23.0940 & 0.015 & 0.035 \\
\hline
\end{tabular}

For explanations see Table 2 
Measurements of Kalvariella typica Morozova (single colony)

\begin{tabular}{|l|r|c|c|c|c|c|}
\hline & $\mathrm{N}$ & $\mathrm{X}$ & $\mathrm{SD}$ & $\mathrm{CV}$ & $\mathrm{MIN}$ & $\mathrm{MAX}$ \\
\hline Aperture width & 10 & 0.090 & 0.0087 & 9.6864 & 0.072 & 0.096 \\
\hline Distance between aperture centres along branches & 10 & 0.293 & 0.0180 & 6.1475 & 0.264 & 0.324 \\
\hline Distance between aperture centres across branches & 10 & 0.266 & 0.0221 & 8.2907 & 0.216 & 0.288 \\
\hline Node diameter & 10 & 0.044 & 0.0068 & 15.6808 & 0.035 & 0.055 \\
\hline Distance between node centres & 6 & 0.220 & 0.0561 & 25.5064 & 0.156 & 0.300 \\
\hline Maximal autozooecial chamber width & 10 & 0.122 & 0.0095 & 7.7881 & 0.100 & 0.135 \\
\hline
\end{tabular}

For explanations see Table 2

Measurements of Acanthocladia anceps (Schlotheim) (three colonies)

\begin{tabular}{|l|r|r|c|c|c|c|}
\hline & $\mathrm{N}$ & $\mathrm{X}$ & $\mathrm{SD}$ & $\mathrm{CV}$ & $\mathrm{MIN}$ & $\mathrm{MAX}$ \\
\hline Main branch width & 10 & 0.645 & 0.0778 & 12.0592 & 0.570 & 0.840 \\
\hline Secondary branch width & 7 & 0.439 & 0.0508 & 11.5856 & 0.384 & 0.540 \\
\hline Distance between centres of secondary branches & 10 & 1.254 & 0.2279 & 18.1776 & 1.050 & 1.800 \\
\hline Aperture width & 20 & 0.077 & 0.0058 & 7.5031 & 0.072 & 0.084 \\
\hline Distance between aperture centres along branches & 20 & 0.293 & 0.0256 & 8.7598 & 0.252 & 0.336 \\
\hline Distance between aperture centres across branches & 20 & 0.248 & 0.0199 & 8.0073 & 0.228 & 0.300 \\
\hline Node diameter & 8 & 0.048 & 0.0080 & 16.8797 & 0.035 & 0.060 \\
\hline Maximal autozooecial chamber width & 10 & 0.121 & 0.0066 & 5.4403 & 0.110 & 0.130 \\
\hline
\end{tabular}

For explanations see Table 2

1850 Acanthocladia anceps (Schlotheim, 1820) - King (1850), p. 48, 49 [partim], pl. 5, figs. 13-18.

1861 Acanthocladia anceps (Schlotheim, 1820) - Geinitz (1861), p. 119, 120 [partim], pl. 22, ?fig. 7.

1930 Acanthocladia anceps (Schlotheim, 1820) - Korn (1930), p. 369, 370, pl. 35 , figs. 8,9 .

1961 Acanthocladia anceps (Schlotheim, 1820) - Dreyer (1961), p. 21, 22, pl. 9 , figs. 2-5.

1970 Acanthocladia anceps (Schlotheim, 1820) - Morozova (1970), p. 240, pl. 57, figs. 2, 3 .

2001 Acanthocladia anceps (Schlotheim, 1820) - Ernst (2001a), p. 147, 148, pl. 6 , fig. 5 , pl. 7 , figs. $1-4$

L e c t o t y p e. - Keratophytes anceps Schlotheim, 1820; K. 57-1. Museum for Natural Sciences, Central Institute of the Humboldt-University, Berlin.

M a t e r i a l e x a m i n e d. - Grodziec (Grodziec Syncline) samples numbered ING UWrPR/Z/Bry/Ca1/15, 23, 35, 38; Lwówek Śląski Syncline ING UWrPR/Z/Bry/Ca1/31; Leszczyna Syncline samples numbered ING UWrPR/Z/Bry/Ca1/3; thin-sections of the samples ING UWrPR/Z/Bry/Ca1/15, mottled marls, ING UWrPR/Z/Bry/Ca1/35, and ING UWr$\mathrm{PR} / \mathrm{Z} / \mathrm{Bry} / \mathrm{Ca} 1 / 38$.

D e s c ription. - Colony consisting of straight main branch with secondary branches. Secondary branches diverging at angles of 77 to $79^{\circ}, 4$ spaced per $5 \mathrm{~mm}$ along the main branch on each side. New branches developed by transformation of secondary branches into main branch or by dichotomy of main branches. Dissepiments or anastomoses absent. Apertures arranged in three alternating rows on main branches and secondary branches. Some secondary branches carry at their beginning only two rows of autozooecia. A short distance after diverging they develop three rows. On main and secondary branches four rows of the autozooecia may infrequently appear. Apertures circular to oval. Autozooecia spaced usually more closely on the secondary branches than on the main branch. Low keels with small nodes between rows of autozooecia. Apparent reproductive polymorphs in form of isolated zooecia with enlarged proximal endozonal chambers common: endozonal chambers $0.144-0.168 \mathrm{~mm}$ in diameter.

Interior description. - Autozooecia relatively short, deep, with a long vestibule; rectangular to hexagonal in mid tangential section; elongate parallel to branch length; aperture positioned at distal to distal-abaxial end of chamber. Short superior hemisepta present; inferior hemisepta absent.

C o m p a r i s o n. - Acanthocladia anceps (Schlotheim, 1820) differs from $A$. laxa Korn, 1930 in generally having thinner branches, and the arrangement of autozooecia on the branches in 3 rows. A. minor possesses thicker branches as well as larger lateral branch angles.

O c c u r r e n c e. - Upper Permian, Ca1, Grodziec (Grodziec Syncline), Leszczyna-Kondratów, Nowy Kościół (Leszczyna Syncline), the upper part of the Ca1; lower part of the Ca1 in Żarska Wieś (Lwówek Śląski Syncline); Acanthocladia anceps was also recorded in the boreholes of the Fore-Sudetic Monocline (Kłapciński, 1971); and the Zechstein of Germany, England, and Lithuania (Korn, 1930; Dreyer, 1961; Morozova, 1970; Ernst, 2001a).

Family FENESTELLIDAE King, 1849

Spinofenestella Termier and Termier, 1971

Ty p e s p e ci e s. - Fenestella spinosa Condra, 1902; Lower Permian, Wolfcampian; North America.

D i a g n o s i s. - Reticulate, fan-shaped as well as funnel-shaped colonies with relatively wide and thick branches and 
relatively thin dissepiments. Autozooecia arranged in two rows on the branches. Autozooecia triangular in mid tangential section, triangular to pentagonal proximal to bifurcations. Narrow keel with single row of nodes developed.

C o m p a r i s o n. - Spinofenestella Termier and Termier, 1971 differs from Rectifenestella Morozova, 1974 in the triangular shape of the autozooecia in mid-tangential section.

O c c u r r e n c e. - Lower Devonian to Upper Permian.

\section{Spinofenestella geinitzi (d'Orbigny, 1850) Figs. 5H-L, 7 and Table 7}

1850 Fenestella geinitzi d'Orbigny, 1850 - d'Orbigny (1850), p. 168. 1861 Fenestella geinitzi d'Orbigny, 1850 - Geinitz (1861), p. 116, pl. 22, fig. 2 1930 Fenestella geinitzi d'Orbigny, 1850 - Korn (1930), p. 355, pl. 1, fig. 6; text-fig. 1

1930 Fenestella retiformis (Schlotheim, 1820)-Korn (1930), p. 354, pl. 1, fig. 3 1961 Fenestella geinitzi d'Orbigny, 1850 - Dreyer (1961), p. 13, pl. 4, figs. 2, 3. 2001 Spinofenestella geinitzi (d'Orbigny, 1850) - Ernst (2001a), p. 152, 153, pl. 9 , fig. 6 , pl. 10, figs. $1-5$.

Holoty pe. - The location of the type material is unknown.

M a t e ri a I e x a m in ed. - Grodziec (Grodziec Syncline) samples numbered ING UWrPR/Z/Bry/Ca1/11, 13, 23, 24; Leszczyna samples ING UWrPR/Z/Bry/Ca1/1-8; thin sections of the samples ING UWr/PR/Z/Bry/Ca1/13 and ING UWr/PR/Z/Bry/Ca1/24.

D e s c r i p t i o n. - Micrometric formula: 14-18.5 (branches per $10 \mathrm{~mm}$ ), 12.5-14 (fenestrules per $10 \mathrm{~mm}$ ), 18-24 (apertures per $10 \mathrm{~mm}$ along the branch). Fan-shaped colony with regular meshwork. Autozooecia arranged on the branches in two alternating rows. Additional autozooecium occurring at branch bifurcations. Dissepiments thin, fenestrules elongatedoval to rectangular with rounded corners, with 3-4 autozooecial apertures per length of a fenestrule. Autozooecial apertures suboctagonal, with eight thin septa in the high peristome. Septa disappear in deeper tangential sections. Narrow keel with a single row of closely spaced nodes present between the rows of the apertures. Nodes long, 4-5 spaced per $1 \mathrm{~mm}$ along the branch. Root-like holdfasts common. Reverse side of the colony strongly ribbed. Internal granular layer well-developed, continuous with obverse keel, nodes, peristomes and across dissepiments. Long and thin rods extend from the inner granular skeleton and reach the reverse side as microstyles. The microstyles are $0.01-0.015 \mathrm{~mm}$ in diameter and regularly spaced. Outer lamellar skeleton moderately thick, usually thickening on the reverse side in the proximal parts of colonies. Heterozooecia absent.

I n t e ri or d e s c ri p t i o n. - Autozooecia triangular to pentagonal in mid tangential section, relatively high and short, with long vestibule; elongate parallel to branch length; aperture positioned at distal to distal-abaxial end of chamber. Superior hemisepta weakly developed; inferior hemisepta absent.

C o m p a ri s o n. - Spinofenestella geinitzi (d'Orbigny, 1850) differs from the other species of the genus in its smaller elements of the meshwork. It differs from S. minuta (Korn, 1930) in its wider and longer fenestrules and in the fan-shaped growth-form compared with the funnel-shaped colony of $S$. minuta.

O c c u r r e n c e. - Ca1, Upper Permian, Grodziec (Grodziec Syncline), Leszczyna Syncline, North Sudetic Basin, Fore-Sudetic Monocline (subsurface) (Kłapciński, 1971), SW Poland; Upper Permian (Zechstein) of Germany and England (Ernst, 2001a).

\section{INTERPRETATION}

The distributional pattern of the bryozoans in the study area is patchy, and associated with a shallow-water biota, forming a biocenoses dominated by bryozoans, brachiopods, and molluscs in distinct horizons usually at the base of the marly calcareous series of the Zechstein Limestone.

The highest bryozoan diversity in the studied profiles occurs in bedded facies, where the fauna is dominated by large, fan-shaped or funnel-shaped colonies of Spinofenestella geini$t z i$, which indicate a low energy environment and moderate or slow sedimentation rates (Raczyński, 1996) typical of offshore or mid- to outer shelf settings on the Ca1 slope and basin floor and soft substrates (Reid, 2010),

Measurements of Spinofenestella geinitzi (d'Orbigny) (two colonies)

\begin{tabular}{|l|r|r|r|r|r|r|}
\hline & $\mathrm{N}$ & $\mathrm{X}$ & \multicolumn{1}{|c|}{$\mathrm{SD}$} & \multicolumn{1}{c|}{ CV } & \multicolumn{1}{c|}{ MIN } & \multicolumn{1}{c|}{ MAX } \\
\hline Branch width & 15 & 0.309 & 0.0250 & 8.1071 & 0.276 & 0.360 \\
\hline Dissepiment width & 15 & 0.113 & 0.0076 & 6.7283 & 0.096 & 0.120 \\
\hline Fenestrule length & 15 & 0.635 & 0.0405 & 6.3752 & 0.540 & 0.690 \\
\hline Fenestrule width & 15 & 0.362 & 0.0723 & 19.9541 & 0.264 & 0.492 \\
\hline Distance between dissepiment centres & 15 & 0.730 & 0.0334 & 4.5727 & 0.690 & 0.780 \\
\hline Distance between branch centres & 15 & 0.610 & 0.0658 & 10.7856 & 0.510 & 0.720 \\
\hline Aperture width & 15 & 0.080 & 0.0054 & 6.7480 & 0.072 & 0.084 \\
\hline Distance between aperture centres along branches & 15 & 0.239 & 0.0140 & 5.8340 & 0.216 & 0.264 \\
\hline Distance between aperture centres across branches & 15 & 0.210 & 0.0231 & 10.9637 & 0.180 & 0.264 \\
\hline Node diameter & 10 & 0.047 & 0.0054 & 11.4358 & 0.040 & 0.055 \\
\hline Distance between node centres & 10 & 0.240 & 0.0271 & 11.3039 & 0.216 & 0.288 \\
\hline Maximal autozooecial chamber width & 15 & 0.122 & 0.0175 & 14.3815 & 0.108 & 0.168 \\
\hline Branches per 10 mm & 5 & 15.790 & 1.7587 & 11.1380 & 14.000 & 18.500 \\
\hline Fenestrules per 10 mm & 6 & 13.130 & 0.5745 & 4.3751 & 12.500 & 14.000 \\
\hline Apertures per $5 \mathrm{~mm}$ along the branch & 6 & 21.933 & 2.0539 & 9.3645 & 18.000 & 24.000 \\
\hline
\end{tabular}


Three types of the colony growth-forms - membraniporiform, reteporiform and vinculariiform - can be distinguished among the bryozoans in the North Sudetic Basin. The dominant colony growth-form (reteporiform) in the Grodziec Syncline belongs to the reticulate fenestellids. In general, the majority of fenestellid colonies occur mostly in the upper part of the Zechstein Limestone, where they are often accompanied by the pinnate colonies of acanthocladiids. Trepostome species, which exhibit an encrusting growth form (membraniporiform) may indicate a shallow depth, moderate to high water energy environment, with low sedimentation rate (cf. Nelson et al., 1988; Reid, 2010) and occur mostly in the marginal parts of the SPB, where reefal/biohermal structures existed during the Ca1 (Leszczyna Syncline). Moreover, they are also abundant and diverse in the lower part of the Ca1 in the western part of the North Sudetic Basin (Lwówek Sląski Syncline) being accompanied by the productid of Horridonia horrida and occurring in a low-energy and low sedimentation accumulation rates if sediment input is low or is trapped onshore.

Bryozoans may have been well-adapted to different, often extreme, ecological settings caused by frequent fluctuations of sea level, sedimentation and distribution of microbial mats (Raczyński, 1996; Peryt et al., 2012). In the study area, bryozoans are a good palaeoecological proxy, clearly reacting to small environmental changes. This is well-observed in the tempestite facies characterized by the highest taxonomic diversity and number of bryozoans. Likewise, bryozoans help to distinguish shelf deposits with no storm beds, thus recording maximum depth and extent of the basin - maximum transgression (Grodziec Syncline)

The recognized bryozoan-bearing strata in SW Poland usually occur at the base of the marly-calcareous series of the Ca1 succession (Table 2 and Fig. 2). Here, they are accompanied by a rich shallow-water biota that includes productid brachiopods (Horridonia horrida), molluscs, benthic foraminifers and fish remains (Fig. 2). The well-marked bryozoan-bearing horizon in the Lwówek Śląski Syncline is mostly confined to the lower part of the Ca1, in contrast to the bryozoans of the Leszczyna Syncline, which occur mostly in the upper part of the Ca1 (Fig. 3) but also in the lower part of the Ca1 (at the base of the mottled limestones, Nowy Kościół locality; Fig. 3). The presence of the transitional and horizontal sedimentary changes in the different parts of the relatively shallow-water North Sudetic Basin, and frequent oscillations of sea level, are clearly indicated in the profiles studied (Fig. 2) by the occurrence of differentiated biotic assemblages and the composition of the bryozoan fauna.

\section{DISCUSSION}

Permian bryozoans, like their modern counterparts, have different growth-forms. Analysis of bryozoan morphotypes has proven to be a valuable tool for palaeoecological interpretation (Stach, 1936; Schopf, 1969; Kelly and Horowitz, 1987; A.M. Smith, 1995; Hageman et al., 1997). Within the North Sudetic Basin these include erect (vinculariiform), fenestellid (reteporiform), and encrusting (membraniporiform) habits. The taxonomically richest bryozoan assemblage occurs in the axial part of the North Sudetic Basin (Grodziec Syncline; Figs. 4-7), where the fauna is dominated by the erect colonies which reveal the reteporiform growth-form and zoaria are composed of large fan-shaped or funnel-shaped colonies of fenestellids with a maximum height of $10 \mathrm{~cm}$. The water energy or turbulence is the primary control on the bryozoans occurrence (Reid, 2010), therefore, we may assume that erect-rigid fenestellids prefer the low energy environment co-occurring with the productid brachiopods which are common in offshore setting with the moderate or slow sedimentation rate and a soft substrate on the slope of the $\mathrm{Ca} 1$ carbonate platform and basin floor (see also Reid, 2010). Colonies of Spinofenestella geinitzi (d'Orbigny) are usually heavily calcified and are a common element of the Ca1 (Figs. 5H-L, 7 and 9B1). They can be used as an efficient indicator of the current system with the ability of forming differently shaped colonies from planar or lobate to fan-shaped or conical-shaped zoaria, probably in response of the water current (Figs. $5 \mathrm{H}-\mathrm{L}$ and 7). Generally, in the lower part of the Grodziec Syncline profile, where the stormy conditions were calmer, the in situ bryozoans show planar to fan-shaped zoaria, and they attain larger sizes, contrary to the upper part of the profile where the currents were stronger and the colonies achieved smaller sizes forming mostly the funnel-shaped zoaria. The overall shape of a bryozoan colony is interpreted as an adaptation to an exterior current flow that both increased the physical stability of the colonies and allowed zooids to generate local currents and filter efficiently nutrients from the water (Cowen and Rider, 1971; McKinney, 1977). According to McKinney and Jackson (1989), reticulate fenestellids are less vulnerable to currents and sedimentation rate, and are able to colonize more exposed sites, of the high to low sedimentation rates and shallow to deep water, but they mostly occur in moderately energetic to relatively quiet environments or microenvironments, either near or below the normal waterbase or in sheltered areas (McKinney and Gault, 1980; Nelson et al., 1988). The majority of reteporiform colonies in the material studied from the Grodziec Syncline form funnel-shaped colonies with the zooecia arranged on the outside of the colony, and some possess well-developed supporting roots; however, smaller cone or funnel-shaped colonies also occur (Figs. 5A, H-L, 6 and 7; cf. Ernst, 2001a). The most delicate, erect-rigid colonies from the marly-calcareous sediments of the Grodziec Syncline are pinnate colonies of Kalvariella typica (Fig. 5B, C), found at the base of the mottled marls of the Ca1, and they usually colonize a very quiet sedimentary environment far from turbulent areas and with very little terrigenous influx (in the bryozoan life time scale).

The zoaria of fenestellids and acanthocladiids together are more common in the upper part of the Ca1 in the Leszczyna Syncline - where they show considerable fragmentation of the colonies, with proximal parts (bases) broken, suggesting highenergy setting, together with the sedimentary features such as the bed bases, graded bedding, as well as a presence of the mollusc coquinas and their connection with the reefal/biohermal structures in the marginal part of the Leszczyna Syncline (Figs. 3 and 8; Raczyński, 1996; Biernacka et al., 2005). Fragments of Acanthocladia anceps colonies recognized in Kondratów locality (Leszczyna Syncline) show their higher stratigraphical and sedimentary cycle position in the studied profile (Table 2 and Fig. 2). They occur in the massive limestones which are evidently connected with the regressive event which terminated the occurrence of the bryozoans in the Ca1.

A very common biofacies in the Grodziec Syncline is composed of Agathammina-Spinofenestella-Horridonia which may indicate a low-energy environment (Fig. 3). The Acanthocladia-Bakevellia-Schizodus is common at Leszczyna (Leszczyna Syncline) and the bryozoans occur there in the upper part of the Ca1, which at that time comprised shallow lagoons separated from a deeper shelf by barriers composed of numerous broken colonies of Acanthocladia (Figs. 1B, C, 2 and 8; Raczyński, 1996). In the lower part of the Ca1 in the Lwówek Ślaski Syncline Dyscritella dominates: it forms encrusting zoaria, colonized often a perished algal substrate (Fig. 9A). Cup-shaped, 
encrusting colonies favour soft-bottoms supported by algae, either using a hard substrate provided by brachiopod shells of Horridonia horrida or echinoid spines (Fig. 9B1). Colonies with a membraniporiform morphotype prefer a low energy, shallow-water, subtidal or lagoonal environment (Lagaaij and Gautier, 1965). It may be suggested that the Lwówek Śląski Syncline deposits originated in a near-shore environment, where the biocenoses of Acanthocladia-Liebea are very common, accompanied by a rich productid-brachiopod and microbial mat association and should be referred to the onshore transgressive-regressive facies in the lower part of the Ca1 (Fig. 2; Raczyński, 1996).

Throughout the Phanerozoic bryozoans have been major sources of carbonate sediment (Taylor and Allison, 1998). During Zechstein Limestone time shallow-water conditions favoured the development of microbial-bryozoan reefal facies, prevailing in the SPB from England (e.g., Smith, 1995) and Germany (Paul, 2010 with references therein), to the eastern part of the basin in Poland (Dyjaczynski et al., 2001) and Lithuania (Morozova, 1970). The common constructors of those reefs are also sessile foraminifers (Peryt et al., 2012).

Ernst's (2001a) study showed that within the SPB in Zechstein time, bryozoans of the order Fenestellida were common to ubiquitous inhabitants of small carbonate bioherms composed of reticulate and pinnate colonies of the following genera: Rectifenestella, Penniretepora, Acanthocladia, Thamniscus, Kingopora, Kalvariella and Synocladia. Cosmopolitan genera such as Rectifenestella and Dyscritella and the endemic genus Kalvariella, are common among German and Polish Zechstein Limestone faunas.

Among the eight species identified from boreholes in Lithuania and the Kaliningrad district (Russia) five (Fenestella retiformis, Kingopora ehrenbergi, Acanthocladia laxa, A. anceps and Kalvariella typica) are distributed in the deposits of NW Europe and only a few are common in Poland (Suveizdis, 1975). Moreover, Kłapciński (1971) showed a certain similarity in existence of the same bryozoan-mollusc-brachiopod associations between the Zechstein Limestone and those of the Permian basins located in Pre-Uralian (Russia) and Salt Range of the Himalaya region (Pakistan).

Considering the northwards palaeobiogeographical connection between the Late Permian Northern Permian Basin fauna of NW Europe and the Arctic Boreal Ocean faunas, it should be mentioned that there are a few taxa in common with eastern North Greenland and Svalbard, such as Dyscritella, Stenopora, Fenestella and Kingopora (Sørensen et al., 2007).

\section{CONCLUSIONS}

In the studied bryozoan fauna from the Zechstein Limestone of the North Sudetic Basin six species belonging to the trepostomids and fenestellids were found. Fenestellids which were likely to have been very common in the marly sections of the Ca1, particularly in the lead-bearing series, occur during the maximum flooding in the axial part of the North Sudetic Basin i.e. Grodziec Syncline.

Factors which contributed to the richness of bryozoans in the North Sudetic Basin included the high availability and abundance of substrates (either hard or soft). Two other important factors such as the favourable current systems and slow or moderate sedimentation rates allowed sufficient time for the colonization of the substrata by the bryozoan biota in the North Sudetic Basin during the Ca1 sedimentation.

The highest faunal taxonomic diversity, including within bryozoans, occurs in the upper part of distal tempestites. This could be interpreted as the effect of improving ecological conditions on the sea-floor and in the bottom waters. This would have allowed a short but intensive development of the sea-floor ecosystem. Analysis of the dominant colony growth-forms in conjunction with the depositional conditions of the Zechstein Limestone marly-calcareous series (mottled, copper- and lead bearing marls) shows that these factors could be correlated with various physical environmental parameters such as current strength, water depth, rate of sedimentation and substrate type.

Acknowledgements. This research was supported by the Polish Geological Institute - Research National Institute (internal projects no. 6.20.9231.00.0 and no. 61.1201.1101.00.0) and by a "Mobility Plus" Programme postdoctoral fellowship of the Ministry of Science and Higher Education of Poland (M.S.). Many thanks are given to J. Błaszyk for a kind assistance during the SEM sessions, and to $Z$. Strak (both from Institute of Paleobiology, PAS) for making the thin-sections. This work benefited from the discussion and kind assistance of A. Ernst during his stay at the PGI-NRI (Warszawa, Poland) as well as from his review of the paper. The authors are very grateful to C.M. Reid, P. Wyse Jackson, H. Arne Nakrem and T. Amund Svånå for their constructive remarks which improved the paper. Many thanks are extended to P.D. Taylor for reading this paper at its early stage and improving the English text. T.M. Peryt is thanked for the critical and editorial remarks of the manuscript.

\section{REFERENCES}

Biernacka J., Borysiuk K., Raczyński P. (2005) Zechstein (Ca1) limestone-marl alternations from the North-Sudetic Basin, Poland: depositional or diagenetic rhythms? Geological Quarterly, 49 (1): 1-14.

Buniak A. Mikołajewski Z., Wagner R. (2007) Mapa paleogeograficzna wapienia cechsztyńskiego (Ca1) w Polsce. Polish Geological Institute, Warsaw. Unpublished.

Cowen R., Rider J. (1971) Functional analysis of fenestellid bryozoan colonies. Lethaia, 5: 145-164.

Dreyer E. (1961) Die Bryozoen des Mitteldeutschen Zechsteins. Freiberger Forschungshefte, C 111: 7-51.

Dyjaczynski K., Górski M., Mamczur S., Peryt T.M. (2001) Reefs in the basinal facies of the Zechstein Limestone (Upper Permian) of Western Poland: a new gas play. Journal of Petroleum Geology, 24: 265-285.
Ernst A. (2001a) Bryozoa of the Upper Permian Zechstein Formation of Germany. Senckenbergiana Lethaea, 81 (1): 135-181.

Ernst A. (2001b) Systematics and biogeography of the Permian Bryozoa in Europe. In: Bryozoan Studies 2001 (eds. P.N. Jackson, C.J. Buttler and M.A.A. Spencer-Jones): 109-112. Balkema Publishers, Lisse.

Geinitz H.B. (1861-1862) Dyas oder die Zechsteinformation und das Rothliegende (permische Formation zum Theil). Leipzig (Verlag von Wilhelm Engelman).

Gilmour E.H., Morozova I.P. (1999) Biogeography of the Upper Permian Bryozoans. Paleontological Journal, 33: 36-51.

Gradstein F.M., Ogg J.G., Schmitz M., Ogg G. (2012) The Geological Time Scale 2012. Elsevier, Amsterdam. 
Gunia T. (1962) The Zechstein of Leszczyna syncline (in Polish with English summary). Biuletyn Instytutu Geologicznego, 174: 57-114.

Hageman S., Bone Y., McGrowran B. (1997) Bryozoan colonial growth-forms as paleoenvironmental indicators: evaluation of methodology. Palaios, 12: 418-436.

Hara U. (2001) Bryozoa - Młodszy paleozoik - Perm In: Budowa geologiczna Polski, Atlas skamieniałości przewodnich i charakterystycznych, T. III Państwowy Instytut Geologiczny, Warszawa, 43-49.

Hara U., Ernst A., Mikołajewski Z. (2009) Permian trepostome bryozoans from the Zechstein Main Dolomite (Ca2) of western Poland and NE Germany. Geological Quarterly, 53 (2): 249-254.

Kelly S.M., Horowitz A.S. (1987) Growth forms and paleoecology of Mississippian bryozoans, critical application of Stach's 1936 Model, Eastern United States. In: Bryozoa Present and Past (ed. J.R.P. Ross): 137-144. Western Washington University.

Kiersnowski H. (2013) Late Permian aeolian sand seas from the Polish Rotliegend Basin in the context of palaeoclimatic periodicity. Geological Society Special Publications, 376.

Kiersnowski H., Peryt T.M., Buniak A., Mikołajewski Z. (2010) From the intra-desert ridges to the marine carbonate island chain: middle to late Permian (Upper Rotliegend-Lower Zechstein) of the Wolsztyn-Pogorzela high, west Poland. Geological Journal: 44, 319-335.

King W. (1850) Monograph of the Permian Fossils of England. Palaeontographical Society, London.

Kłapciński J. (1971) Lithology, fauna, stratigraphy and palaeogeography of the Permian in the Fore-Sudetic monocline (in Polish with English summary). Geologia Sudetica, 5: 77-135.

Kłapciński J., Karwowski L. (1981) Stratigraphical analysis of the Zechstein deposits in Western Poland based on macrofauna studies. Proceedings of International Symposium on Central European Permian, Jabłonna, April 27-29, 1978: 490-499.

Korn H. (1930) Die cryptostomen Bryozoen des deutschen Perms. Leopoldina, 6: 341-375.

Lagaaij R., Gautier Y.V. (1965) Bryozoan assemblage from marine sediments of the Rh ne delta France. Micropaleontology, 11: 37-58.

Langenhan A. (1899) Über einige Zechstein-Versteinerungen aus Schlesien. Jahres-Bericht der Schlesischen Gesellschaft fur vaterlandische Kultur, 77: 44-52.

Mastalerz K., Raczyński P. (1993) Litostratygrafia i ewolucja basenu północnosudeckiego w karbonie i permie. In: Baseny sedymentacyjne: procesy, osady, architektura (eds. K. Mastalerz, L. Kurowski and P. Raczyński): 90-96. II Krajowe Spotkanie Sedymentologów. Wrocław - Sudety, 4-7 września.

McKinney F.K. (1977) Functional interpretation of lyre-shaped Bryozoa. Paleobiology, 3: 90-97.

McKinney F.K., Gault H. (1980) Paleonvironment of Late Mississippian fenestrate bryozoans, eastern United States. Lethaia, 13: 127-146.

McKinney F.K., Jackson J.B.C. (1989) Bryozoan evolution. The University of Chicago Press, London.

Morozova I.P. (1970) Upper Permian Bryozoa (in Russian). Trudy Paleontologicheskogo Instituta Akademii Nauk SSSR, 122.

Morozova I.P. (2001) Bryozoans of the order Fenestelida (in Russian). Trudy Paleontologicheskogo Instituta, 277: 1-176.

Morozova I.P., Krutschinina O.N. (1986) Permian Bryozoans of the Arctic (Western Sector) (in Russian). Nauka, Moscow.

Nakrem H.A. (1994) Bryozoans from the Lower Permian Voringen member (Kapp Starostin Formation), Spitsbergen, Svalbard. Norsk Polarinstitut Skrifter, 196: 1-93.

Nelson C.S., Hyden F.M., Keane S.L., Leask W.L., Gordon D.P. (1988) Application of bryozoan zoarial growth-form studies in facies analysis of non-tropical carbonate deposits in New Zealand. Sedimentary Geology, 60: 301-322.

Paul J. (2010) Zechstein reefs in Germany. In: Petroleum Geological Atlas of the Southern Permian Basin Area (eds J.C. Doornenbal and A.G. Stevenson): 142-144. EAGE Publications b.v. Houten.
Peryt D., Peryt T.M., Raczyński P., Chłódek K. (2012) Foraminiferal colonization related to the Zechstein (Lopingian) transgression in the western part of the Wolsztyn Palaeo-Ridge area, Western Poland. Geological Quarterly, 56 (3): 529-546.

Peryt T.M. (1978) Outline of the Zechstein stratigraphy in the North Sudetic Trough (in Polish with English summary). Kwartalnik Geologiczny, 22 (1): 59-82.

Peryt T.M., Geluk M.C., Mathiesen A., Paul J. and Smith K. (2010) Zechstein. In: Petroleum Geological Atlas of the Southern Permian Basin Area (eds. J.C. Doornenbal and A.G. Stevenson): 123-147, EAGE Publications b.v, Houten.

Peryt T.M., Raczyński P., Peryt D., Chłódek K. (2012) Upper Permian reef complex in the basinal facies of the Zechstein Limestone (Ca1), western Poland. Geological Journal, 47: 537-552.

Raczyński P. (1996) Paleontologiczne i sedymentacyjne wskaźniki warunków powstawania osadów w cechsztynie niecki północnosudeckiej. Ph.D. thesis, University of Wrocław.

Raczyński P. (1997) Depositional conditions and paleoenvironments of the Zechstein deposits in the North-Sudetic basin (SW Poland) (in Polish with English summary). Przegląd Geologiczny, 45 (7): 693-699.

Raczyński P. (2010) North-Sudetic Basin: nearshore carbonate and siliciclastic deposits. In: Petroleum Geological Atlas of the Southern Permian Basin Area. (eds. J.C. Doornenbal and A.G. Stevenson): 142. EAGE Publications b.v, Houten.

Reid C.M. (2010) Environmental controls on the distribution of Late Paleozoic bryozoan colony morphotypes: en example from the Permian of Tasmania, Australia. Palaios, 25: 692-702.

Riedel H. (1917) Die Fossilführung des Zechsteins von Niederschlesien. PhD dissertation, Halle.

Schlotheim E.F. (1820) Die Petrefactenkunde auf ihrem jetzigen Standpunckte durch die Beschreibung seiner Sammlung versteinerter und fossiler Uberreste des Thier- und Planzenreichs der Vorwelt erlautert. I-LXII, Gotha (Becker).

Schopf T.J.M. (1969) Paleoeclogy of ectoprocts (bryozoans). Journal of Paleontology, 43: 234-244.

Smith A.M. (1995) Paleoenvironmental interpretation using bryozoans: a review. Geological Society Special Publications, 83: 235-243.

Smith D.B. (1995) Marine Permian in England. Chapman and Hall, London.

Southwood D.A. (1985) The taxonomy and paleoecolgy of Bryozoa from the Upper Permian Zechstein reef of N.E. England. Unpublished Ph. D. thesis, University of Durham.

Southwood D.A. (1990) New bryozoan taxa from the Upper Permian Zechstein reef in N.E. England. Proceedings of the Yorkshire Geological Society, 48: 33-40.

Sørensen A.M., Håkansson E., Stemmerik L. (2007) Faunal migration into the Late Permian Zechstein Basin - evidence from bryozoan palaeobiogeography. Palaeogeography, Palaeoclimatology, Palaeoecology, 251: 198-209.

Stach L.W. (1936) Correlation of zoarial forms with habit. Journal of Geology, 44: 60-65.

Suveizdis P.I. (1975) Permian deposits of Baltic area (stratigraphy and fauna) (in Russian). Department of Geology under the council of Ministers of Lithuanian SSR. Publishing House "Minitis" Vilnius.

Taylor P.D. (1980) Stomatopora voigtiana (King 1850): a cyclostome bryozoan from the Permian of County Durham. Proceedings of the Yorkshire Geological Society, 42: 621-626.

Taylor P.D. (1985) Carboniferous and Permian species of the cyclostome bryozoan Corynotrypa Bassler, 1911 and their clonal propogation. Bulletin of the British Museum (Natural History) (Geology Series), 38: 359-372.

Taylor P.D., Allison P.A. (1998) Bryozoan carbonates through time and space. Geology, 26: 459-462.

Zimmerman L.S., Cuffey R.J. (1987) Species involved in Permian bryozoan bioherms, west Texas In: Bryozoa Present and Past (ed. J.R.P. Ross): 309-316. Western Washington University. 